\title{
OPETANIE I EGZORCYZMY W APOLOGETYCE WCZESNOCHRZEŚCIJAŃSKIEJ II-III WIEKU
}

Egzorcyzmy rozumiane w szerokim sensie jako uwolnienie człowieka od stanu opętania, nie są zjawiskiem zarezerwowanym wyłącznie dla chrześcijaństwa, lecz spotykanym w wielu kulturach ${ }^{1}$. Orygenes zaświadcza bowiem nie tylko o istnieniu egzorcystów żydowskich, ale również o tego typu praktykach istniejących wśród egipskich czarowników ${ }^{2}$. Nowy Testament często ukazuje Chrystusa, który za pomocą rozkazu wydanego złemu duchowi uwalnia zniewolonego człowieka (np. Mt 17, 18; Mk 1, 25; Łk 4, 35). Władzy tej udziela również swym uczniom, których posyła po dwóch przed sobą, by zwiastowali nadejście królestwa Bożego (Mt 10, 5-10), a następnie nakazuje Kościołowi korzystanie z niej jako ze skutecznego narzędzia w głoszeniu Ewangelii (Mk 16, 17). Dzieje Apostolskie ukazują, że korzystał z niej św. Paweł Apostoł w swej posłudze głoszenia słowa Bożego (Dz 16, 16-21; 19, 11-12), zaś znaki, jakich dokonywał wzywając nad chorymi i opętanymi imienia Jezusa, zwiastowały obecność królestwa Bożego ${ }^{3}$. Kościół pierwotny przejął tę praktykę stosując tę modlitwę zarówno wobec opętanych, jak i katechumenów, wiążąc ją w ten sposób z sakramentem chrztu ${ }^{4}$, a sam egzorcyzm, początkowo traktowany jako rodzaj posługi charyzmatycznej dostępnej dla szerokiego grona chrześcijan, z czasem przybierał postać rytu określonego przez Kościół i dostępnego jedynie dla wybranych chrześcijan ${ }^{5}$.

\footnotetext{
${ }^{*}$ Ks. dr Mariusz Terka - wykładowca patrologii w Wyższym Instytucie Teologicznym w Częstochowie; e-mail: mariuszterka0@op.pl.

${ }^{1}$ Por. A.J. Nowak, Egzorcyzm, w: Leksykon teologii fundamentalnej, red. M. Rusecki - K. Kaucha - I.S. Ledwoń - J. Mastej, Lublin - Kraków 2002, 342; M. Ott, Exorcismus. Religiongeschichtlich, LThK $^{3}$ III 1125-1126.

${ }^{2}$ Por. Origenes, Contra Celsum I 22, ed. M. Borret, SCh 132, Paris 1967, 130-132, thum. S. Kalinkowski: Orygenes, Przeciw Celsusowi, Warszawa 1986, 50; tamże IV 33, SCh 136, 266-268, thum. Kalinkowski, s. 205.

${ }^{3}$ Por. W. Głowa, Egzorcyzm, EK IV 735-736. Szerzej na temat egzorcyzmu w posłudze św. Pawła Apostoła zob. R. Pindel, Magia czy Ewangelia, Kraków 2003, 311-336; S. Zalewski, Walka z osobowym złem. Studia o postudze egzorcyzmowania w Kościele Katolickim, Płock 2013, 176-193; W. Kirchschläger, Exorcismus. Biblisch, LThK ${ }^{3}$ III 1126.

${ }^{4}$ Por. B. Nadolski, Liturgika. Sakramenty, sakramentalia, blogosławieństwa, III, Poznań 1992, 250-252; Głowa, Egzorcyzm, s. 736.

${ }^{5}$ Por. Constitutiones apostolorum VIII 1, 1-2, ŹMT 42 = SCL 2 [wyd. grecko-polskie], 215;
} 
U podstaw praktyki egzorcyzmu znajduje się przekonanie o tym, że człowiek może doświadczać napaści ze strony złego ducha, a nawet zostać przez niego opanowany ${ }^{6}$, co z kolei zakłada istnienie komunikacji i wzajemnego oddziaływania na siebie świata ludzi i duchów. By zrozumieć to zjawisko należy postawić pytanie o warunki możliwości jego zaistnienia, czyli podjąć próbę ukazania duchowego wymiaru tej rzeczywistości, która stoi u podstaw opętania oraz egzorcyzmu. Odsłania się ona w pełni w perspektywie teologicznej ${ }^{7}$. Dopiero w niej bowiem zrozumiała staje się kościelna praktyka egzorcyzmów oraz problem duchowych zniewoleń. Jako materiał źródłowy, rzucający światło na te zjawiska, zostały wybrane apologie wczesnochrześcijańskie II i III wieku, gdyż ich autorzy, spotykając się z doświadczeniem modlitwy Kościoła za ludzi opętanych, zbudowali w ramach dialogu z kulturą antyczną, teologiczne podstawy do zrozumienia tej praktyki. Chociaż nie stanowiła ona głównego tematu dyskusji z poganami, to jednak była znaczącym argumentem w polemice z przedstawicielami kultury antycznej.

\section{OPETANIE}

Apologeci wczesnochrześcijańscy pisząc o opętaniach i zniewoleniach duchowych, odwołują się najpierw do codziennego doświadczenia członków Kościoła, którzy w praktyce swej wiary spotykali się z tego typu zjawiskami. Można nawet uznać, że były one poważnym problemem duszpasterskim i wyzwaniem dla Kościoła, szczególnie na gruncie misji ewangelizacyjnej oraz w odniesieniu do pogan wstępujących do wspólnoty Kościoła. Teofil z Antiochii podkreśla bowiem, że opętania i egzorcyzmy nie są zapomnianymi zjawiskami z odległej przeszłości, lecz rzeczywistością jemu współczesną ${ }^{8}$. Natomiast Justyn Męczennik zaświadcza o istnieniu licznych opętanych, żyjących nie tylko gdzieś daleko w świecie, ale także w samym Rzymie. Stąd też adresaci jego Apologii mogą pośród nich odnaleźć własnych współobywateli ${ }^{9}$. Przekaz ten potwierdzają również Tacjan Syryjczyk oraz Minucjusz Feliks, zauważa-

tamże VIII 26, 1-3, SCL 2, 256; R. Messner, Exorcistat, LThK ${ }^{3}$ III 1129; A. Montan, Il ministro: carisma o instituzione?, w: Tra maleficio, patologie e possessione demoniaca. Teologia e pastorale dell'esorcismo, ed. M. Sodi, Padova 2003, 290; Zalewski, Walka z osobowym złem, s. 194.

${ }^{6}$ Por. Nowak, Egzorcyzm, s. 342; P. Wygralak, Stanowisko Kościoła wobec idolatrii i magii na terenach Galii i Hiszpanii w późnej starożytności chrześcijańskiej (VI-VII w.), Poznań 2011, 228233; K. Mielcarek, Opętanie. W Biblii, EK XIV 643-646.

${ }^{7} \mathrm{Z}$ tego powodu nie jest celem niniejszego artykułu prezentowanie historycznego aspektu liturgii egzorcyzmu, lecz teologiczne ujęcie tego zjawiska, a tym samym próba ukazania duchowych przyczyn, jakie stoją za opętaniem i wyzwalaniem z niego.

${ }^{8}$ Por. Theophilus Antiochenus, Ad Autolycum II 8, 8, ed. G. Bardy, SCh 20, Paris 1948, 116118, thum. L. Misiarczyk: Teofil z Antiochii, Do Autolika, w: Pierwsi apologeci greccy, BOK 24, Kraków 2004, 405.

${ }^{9}$ Por. Iustinus, Apologia II 5(6), 6, ed. Ch. Munier, SCh 507, Paris 2006, 334, thum. L. Misiarczyk: Justyn Męczennik, 2 Apologia, BOK 24, 275-276. 
jąc, że ludzi zniewolonych przez złe duchy można spotkać w wielu miejscach publicznych, na ulicach oraz w pobliżu świątyń pogańskich ${ }^{10}$.

Skoro pojawianie się ludzi znajdujących się pod wpływem złych duchów nie było dla chrześcijan pierwszych wieków wyjątkowym i odosobnionym przypadkiem, to wydaje się być rzeczą konieczną spojrzenie najpierw na pewne zewnętrzne znaki, na podstawie których Kościół rozpoznawał ich działanie w danym człowieku, by następnie odpowiedzieć na pytanie o warunki możliwości duchowych zniewoleń.

1. Fenomen opętania. Tertulian podkreśla, że oddziaływanie złych duchów na człowieka i świat materialny nie jest bezpośrednio uchwytne dla ludzkiego umysłu, dlatego też można je poznać jedynie po skutkach, jakie te duchy wywołują w zachowaniu człowieka. Sprowadzają one na ludzi szaleństwa (furor), choroby umysłowe (amentia foeda), rozbudzają w nich namiętności (libido) prowadząc w ten sposób do uwikłania w rozmaite błędy (error), wśród których szczególne miejsce zajmuje kult bałwochwalczy. Są oni zatem ludźmi o obłąkanym umyśle ${ }^{11}$. Tacjan podaje, że złe duchy budzą w opętanych szaleństwo ( $\left.\alpha \beta \varepsilon \lambda \tau \varepsilon \rho^{\prime} \alpha\right)$, które nazywa również chorobą (morbus) ${ }^{12}$, a Justyn stwierdza, że tych, którzy znaleźli się pod ich wpływem, nazywano powszechnie opętanymi ( $\delta \alpha \iota \mu \nu \imath o ́ \lambda \eta \pi \tau o \varsigma)$ i szaleńcami ( $\mu \alpha \imath v o ́ \mu \varepsilon v o \varsigma)^{13}$. Również Orygenes zauważa, że opętani ludzie często wpadają w szaleństwo, choć nie jest to stan stały i niekiedy odzyskują przytomność umysłu ${ }^{14}$.

Interesujący opis wpływu złych duchów na człowieka pozostawił Minucjusz Feliks. Pisząc o ich działaniu w następujący sposób:

„Ściągają więc ludzi z nieba w dół, odwodzą od Boga prawdziwego zastępując go materią, wprowadzają w życie zamęt, niepokoją we śnie, potrafią wkraść się niezauważalnie w ciała, gdzie jako przenikliwe duchy, sieją strach, sprowadzają na ludzi choroby, powodując zwichnięcia członków, gdyż chcą przez to zmusić do oddawania sobie czci i stwarzając pozory, że nasyceni dymami dobywającymi się z ołtarzy oraz ofiarami z bydląt wydają się uwalniać od pęt, jakie sami nam nałożyli. Do tych opętanych należą zarówno rozmaici

${ }^{10}$ Por. Tatianus, Oratio ad Graecos 18, ed. PG 6, 848, thum. L. Misiarczyk: Tacjan Syryjczyk, Mowa do Greków, BOK 24, 332; Minucius Felix, Octavius 27, 3, PL 3, 338-339, thum. M. Szarmach: Minucjusz Feliks, Oktawiusz, w: Apologie, PSP 44, Warszawa 1988, 61.

${ }^{11}$ Por. Tertullianus, Apologeticum XXII 5-6, ed. E. Dekkers, CCL 1, Turnhout 1954, 129, thum. J. Sajdak: Tertulian, Apologetyk, POK 20, Poznań 1947, 106.

${ }_{12}$ Por. Tatianus, Oratio ad Graecos 16, PG 6, 841, BOK 24, 329; J. Pałucki, Chrystus Boski Lekarz, w pismach Klemensa Aleksandryjskiego, w: Wczesnochrześcijańska asceza. Zagadnienia wybrane, red. F. Drączkowski - J. Pałucki, Lublin 1983, 16-18.

${ }^{13}$ Por. Iustinus, Apologia I 18, 4, ed. Ch. Munier, SCh 507, 180, thum. L. Misiarczyk: Justyn Męczennik, 1 Apologia, BOK 24, 220; L. Winniczuk, Ludzie, zwyczaje obyczaje starożytnej Grecji i Rzymu, II, Warszawa 1983, 678-679.

${ }^{14}$ Por. Origenes, Contra Celsum VIII 66, ed. M. Borret, SCh 150, Paris 1969, 326, thum. Kalinkowski, s. 419-420. 
nawiedzeni, których widać na ulicach, jak i prorocy, oraz ci, co szwędają się z dala od świątyń, gdzie dostępując natchnienia głośno krzyczą. Wszyscy oni mają na sobie to samo piętno demona, chociaż u każdego z nich szaleństwo owo inaczej się objawia"15.

Uwagi o szaleństwie, dziwnym, bo odbiegającym od normy zachowaniu, o strachu, niepokojach we śnie sugerują, że apologeci wczesnochrześcijańscy opisują nie tyle opętanie, ile jakiś rodzaj choroby, która wpływając na umysł człowieka, powoduje pewne zmiany w jego ciele oraz w zachowaniu, a używają terminu ,opętanie”, gdyż jest on dostępny dla języka religijnego i daje odpowiedź na pytanie o te niezrozumiałe dla nich zjawiska. Tego rodzaju scjentystycznej interpretacji przeczą jednak teksty samych apologetów. Określenia dotyczące szaleństwa mają bowiem przede wszystkim kontekst religijny i w takiej perspektywie muszą być wyjaśniane. Justyn odnosi je przede wszystkim do pogańskich wyroczni w rodzaju Amfilocha, Dodony czy też Pytii $^{16}$, zaś Teofil z Antiochii pisze wprost o demonach, które inspirowały starożytnych poetów greckich, a wśród nich Homera i Hezjoda oraz utwierdzały ich w błędzie idolarii ${ }^{17}$. Orygenes natomiast zauważa, że działanie ducha okrywającego ciemnością ludzki umysł szczególnie widoczne jest w postaci Pytii, która wieszcząc oszołomiona i nieprzytomna, czerpie natchnienie od demona zwanego przez Greków Apollonem. Natomiast w przeciwnym wypadku, kiedy umysł ludzki nawiązuje kontakt z Bogiem, staje się coraz jaśniejszy i szlachetniejszy, gdyż Duch Boży nie zsyła na proroka ekstazy, szału, czy obłędu ${ }^{18}$. To bowiem ludzie bezbożni są określani mianem nierozumnych oraz poddanych namiętnościom i błędom ${ }^{19}$, a ich bunt przeciw Bogu określany jest

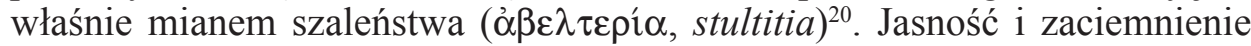
umysłu zależy więc od jego otwarcia na Boga lub demona, co oznacza, że

${ }^{15}$ Minucius Felix, Octavius 27, 2-3, PL 3, 338-339: „Sic coelo deorsum gravant, et a Deo vero materias avocant, vitam turbant, omnes inquietant, irrepentes etiam corporibus occulte, ut spiritus tenues, morbos fingunt, terrent mentes, membra distorquent, ut ad cultum sui cogant: ut nodore altarium, vel hostiis pecudum saginati, remissis, quae constrinxerant curasse videantur. Hi sunt et furentes, quos in publicum videtis excurrere; vates et ipsi absque templo sic insaniunt, sic bacchantur, sic rotantur. Par et in illis instigatio daemonis, sed argumentum dispar furoris”, PSP 44, 61.

${ }^{16}$ Por. Iustinus, Apologia I 18, 4, SCh 507, 180, BOK 24, 220.

${ }^{17}$ Por. Theophilus Antiochenus, Ad Autolycum II 8, 7, SCh 20, 116-118, BOK 24, 405. Teofil nie jest jednak w tym poglądzie konsekwentny, gdyż jednocześnie podkreśla, że dusze niektórych spośród poetów doznawały duchowego przebudzenia i wówczas wygłaszali oni nauki zgodne ze świadectwami proroków. Nie zmienia to jednak ogólnej zasady teologii Teofila, w myśl której uznaje on, iż poeci pogańscy nie znali prawdy i tkwili w błędach utwierdzani w nich przez demony. Wydaje się zatem, że tej ogólnej diagnozy dotyczącej źródeł natchnienia poetów pogańskich nie można sprowadzić do konwencji literackiej apologii, czy też usprawiedliwiać doszukując się niechęci Autora do kultury greckiej.

${ }^{18}$ Por. Origenes, Contra Celsum VII 3-4, SCh 150, 17-18, thum. Kalinkowski, s. 342.

${ }^{19}$ Por. Iustinus, Apologia I 57, 1, SCh 507, 280, BOK 24, 248.

${ }^{20}$ Por. Tatianus, Oratio ad Graecos 7, PG 6, 821, BOK 24, 318. 
zjawiska te posiadają podłoże duchowe, które może zostać właściwie ujęte dopiero w pespektywie teologicznej ${ }^{21}$.

Argumentem za słusznością takiego rozumienia owego szaleństwa i źródeł natchnienia dla wieszczów jest dla apologetów również kościelna praktyka egzorcyzmów. Podają oni bowiem, że złe duchy wychodzące z ludzi opętanych, same przyznają, iż są tymi samymi duchami, które działały niegdyś w poetach pogańskich ${ }^{22}$, inspirowały wieszczów w rodzaju Pytii i innych fałszywych proroków, uchodziły za uzdrowicieli ${ }^{23}$, czy też podawały się za bogów przyjmując imiona Saturna, Serapisa, Jowisza i wielu innych, znanych kulturze antycznej postaci ${ }^{24}$.

${ }^{21}$ Wydaje się, że podkreślenie tego faktu jest niezmiernie istotne dla właściwego zrozumienia zjawiska, które apologeci wczesnochrześcijańscy określili mianem opętania. Zdarza się bowiem, że opętania jest utożsamiane $\mathrm{z}$ epilepsją ze względu na podobieństwo w zewnętrznym zachowaniu człowieka dotkniętego chorobą i zniewolonego przez złego ducha. W taki sposób interpretuje się niektóre ewangeliczne opisy uzdrowień dokonanych przez Jezusa, umieszczając je w kontekście ludowych wierzeń, że przyczyną chorób i cierpień są demony (np: Łk 9, 39, por. J. Gnilka, Jezus z Nazaretu, thum. J. Zychowicz, Kraków 2005, 162-163-166). Podobnie interpretuje te zjawiska thumacz Apologetyku Tertuliana (por. POK 20, 105, nota 4), który zamieszczając w przypisach analogiczne do zawartych w piśmie Kartagińczyka opisy opętania obecne w Oktawiuszu Minucjusza Feliksa (tamże 27, 2, PL 3, 338, PSP 44, 61), umieszcza w tekście tego ostatniego własną diagnozę - epilepsja, której w zapisie oryginalnym nie ma. Tymczasem na oznaczenie szaleństwa związanego ze zjawiskiem, które nazywa opętaniem używa on terminu furor -oris, (tamże PL 3, 339, PSP 44, 61), który oznacza: „szał, obłęd, szał bachancki, trans, uniesienie wieszcze, natchnienie poetyckie, bezczelność, zaślepienie, zapalczywość, pychę, popędliwość, okrucieństwo, pożądliwość, namiętność" (por. Plezia II 622-623). Posiada ono zatem znacznie więcej określeń, które kierują się bardziej ku uznaniu jakiegoś wpływu duchowego niż zwykłej choroby. Nie rozstrzygają one jednak problemu, gdyż nawet trans, czy wieszcze uniesienie nie musi mieć podłoża demonicznego. Niemniej jednak na taki właśnie wpływ wskazuje Orygenes (Contra Celsum VIII 66, SCh 150, 326, tłum. Kalinkowski, s. 419-420), który pisząc o szaleństwie, w jakie wpadają opętani stwierdza: „Eî̀ $\tau \alpha$ đó $\lambda \iota v$

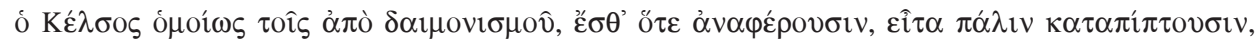

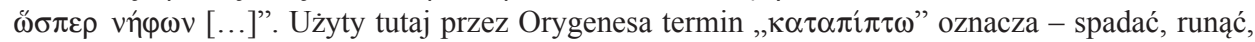
padać, chorować na padaczkę (por. Stownik grecko-polski, opr. O. Jurewicz, I, Warszawa 2000, 508). Możliwe jest zatem zinterpretowanie tego zjawiska w kategoriach zwyczajnej choroby, ale także jako zjawiska o podłożu duchowym, gdyż Orygenes umieszcza te objawy w kontekście wpływu demonicznego i opętania. Skoro zatem możliwe są obydwie interpretacje, to nie ma żadnego powodu, dla którego należałoby przyjąć tylko wersję epilepsji, a odrzucić możliwość wpływu złego ducha, tym bardziej, że tę właśnie interpretację przyjmują apologeci. Z drugiej zaś strony niejednoznaczność ta sprzyja postawie ostrożności w stawianiu diagnozy zabezpieczając przed nadmiernym dopatrywaniem się działanie diabelskiego tam, gdzie ono nie zachodzi. Por. R. Garrigou-Lagrange, Trzy okresy życia wewnętrznego wstępem do życia w niebie, tłum. T. Landy, Niepokalanów 2001, 892-899; B. Zarzycka, Opętanie. W Psychologii, EK XIV 644-646; H. Witczyk, Opętanie, w: Stownik Teologiczny, II, red. A. Zuberbier, Katowice 1989, 38.

${ }^{22}$ Por. Theophilus Antiochenus, Ad Autolycum II 8, 8, SCh 20, 118, BOK 24, 405.

${ }^{23}$ Por. Tertullianus, Apologeticum XXII 9-10, CCL 1, 129-130, POK 20, 107.

${ }^{24}$ Por. Origenes, Contra Celsum VII 3-4, SCh 150, 18-22, thum. Kalinkowski, s. 342; Minucius Felix, Octavius 27, 5-6, PL 3, 339, PSP 44, 61. Fakt, iż apologeci nie podają imion złych duchów 
Uznanie za wiarygodny opis pozostawiony przez apologetów wczesnochrześcijańskich nie wyjaśnia jeszcze istoty zjawiska opętania, lecz otwiera dopiero perspektywę, z której może ona zostać dostrzeżona. Skoro bowiem u jego podstaw znajduje się działanie demoniczne, to należy zapytać o to, na czym ono polega i jakie więzy łączą człowieka ze złymi duchami, czyli - jak możliwe jest opętanie.

2. Władza demonów nad człowiekiem. Jakkolwiek termin „demon” ( $\delta \alpha i ́ \mu \omega \nu, \delta \alpha \iota \mu o ́ v ı v)$ nie zawsze posiadał w kulturze greckiej pejoratywne zabarwienie, gdyż nazywano w ten sposób po prostu dobre lub złe bóstwo opiekuńcze ${ }^{25}$, to jednak przez autorów biblijnych oraz Ojców Kościoła jest on z reguły utożsamiany z duchem nieczystym (spiritus insincerus, spiritus impurus), który zbuntował się przeciwko Bogu ${ }^{26}$. Tacjan Syryjczyk ujmuje tę reprezentatywną dla pisarzy wczesnochrześcijańskich myśl w następujących słowach:

„Lecz gdy ludzie wraz z niektórymi aniołami postanowili iść za najbardziej inteligentnym i stworzonym jako pierwszy spośród innych aniołów, nazywając wręcz bogiem tego, który zbuntował się przeciw Prawu Bożemu, wtedy moc Logosu wykluczyła inicjatora owego szaleństwa i jego zwolenników ze wspólnoty ze sobą. I tak oto człowiek, który został stworzony na obraz Boga, gdy oddalił się od niego potężniejszy Duch, stał się śmiertelny. Natomiast ów pierworodny anioł z powodu swojego szaleńczego występku i wykroczenia zmienił się w demona, zaś ci, którzy go naśladowali, stali się namiastką zastępu demonów. A ponieważ posiadają wolną wolę zostali pozostawieni ich własnemu szaleństwu"27.

znanych z Biblii, a eksponują imiona znane w kulturze grecko-rzymskiej wynika po prostu z kierunku polemiki wymierzonej w bałwochwalstwo pogan.

${ }^{25}$ Por. D. Harmening, Dämon, LThK ${ }^{3}$ III 1-2; F. Skaźnik - H. Zimoń, Demon. W religiach pozachrześcijańskich, EK III 1158-1159.

${ }^{26}$ Por. Minucius Felix, Octavius 26, 8, PL 3, 335, PSP 44, 59; tamże 27, 1, PL 3, 336, PSP 44, 60; R. Popowski, Wielki słownik grecko - polski Nowego Testamentu, Warszawa 2006, 117; Harmening, Dämon, s. 3-4; L. Stachowiak, Demon. W Starym Testamencie, EK III 1159-1560; J. Szlaga, Demon. W Nowym Testamencie, EK III 1160.

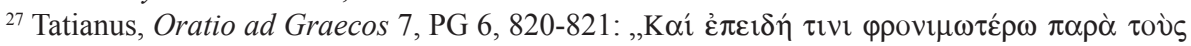

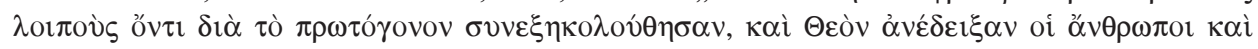

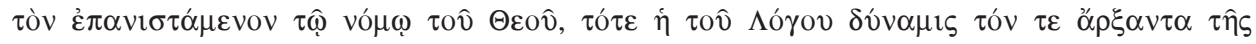

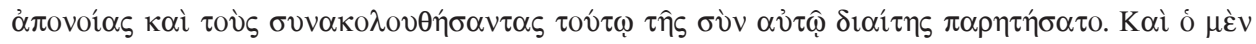

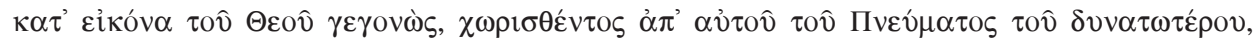

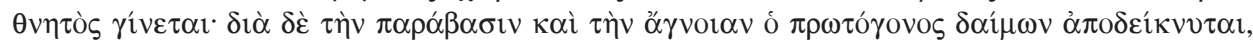

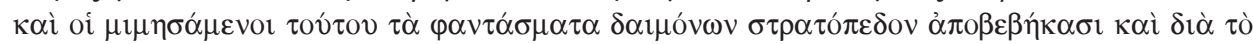

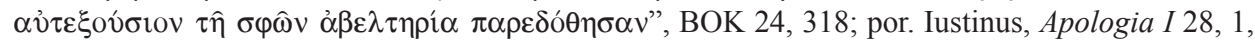
SCh 507, 204, BOK 24, 226; Origenes, Contra Celsum IV 92, ed. M. Borret, SCh 136, Paris 1968, 415, tłum. Kalinkowski, s. 241-242. Należy jednak pamiętać o tym, że pomiędzy poszczególnymi apologetami występują różnice w ujęciu problematyki demonologicznej, które wynikają z różnych antropologii, z wpływu gnostycyzmu na ich poglądy, czy też innych jeszcze przyczyn. Niemniej jednak wszyscy Ojcowie Kościoła zgadzają się co do tego, że należy utożsamić demony ze złymi 
Demony te, same pogrążone we własnych nieprawościach i napełnione złością oraz nienawiścią ${ }^{28}$ do ludzi, którym zazdroszczą łaski Bożej ${ }^{29}$, usiłują ich oderwać od Boga i sprowadzić z drogi sprawiedliwości ${ }^{30}$. Podstawowym ich celem jest zatem zniszczenie człowieka (eversio hominis) ${ }^{31}$ wyrządzenie mu jakiejś krzywdy ${ }^{32}$ lub (i) zniewolenie go $^{33}$. Owo opanowanie człowieka przez złe duchy i atak na niego może dotyczyć jego ciała (corpus), ale także duszy (anima) $)^{34}$.

Tacjan opisując to zjawisko, stwierdza, że ci, którzy są uznawani za bogów, wchodzą w ciała niektórych osób i mogą na nie oddziaływać, zsyłając choroby ${ }^{35}$, łącznie z czymś, co Minucjusz Feliks nazywa zwichnięciem członków (membra distorquent), a nawet stać się przyczyną określonego zachowania opanowanych przez siebie ludzi ${ }^{36}$. Oddziaływanie to nie jest jednak tylko chwilowym dręczeniem, lecz nosi cechy stałej obecności złego ducha, rozciągającej się od momentu opętania aż do zupełnego wyzwolenia od jego wpływu, choć nie oznacza ono zupełnej utraty panowania człowieka nad swym zachowaniem $^{37}$. Tacjan zauważa bowiem, że demony zawłaszczając ludzkie

duchami oraz postawić znak równości pomiędzy nimi a bogami czczonymi przez pogan. Wszyscy też uznawali możliwość negatywnego wpływu demonów na człowieka i świat materialny, choć stopień tego oddziaływania określony był przez poglądy poszczególnych pisarzy na temat wartości kultury grecko-rzymskiej oraz jej relacji do chrześcijaństwa. Jest to jednak zagadnienie obszerne i przekraczające ramy niniejszego artykułu, dlatego też nie jest jego celem przedstawienie demonologii Ojców Kościoła. Zaakcentowane zostaną w nim tylko te elementy nauczania pisarzy wczesnochrześcijańskich o demonach, które wydają się być niezbędne do właściwego opisu ich poglądu na zjawisko opętania i praktykę egzorcyzmu, zob. np. Lactantius, Divinae Institutiones 2, 14-16, ed. P. Monat, SCh 337, Paris 1987, 184-204; Augustinus, Enarrationes in Ps. 44, 2, ed. D.E. Dekkers I. Fraipont, CCL 38, Turnhout 1956, 494. Z tego powodu w dalszej części artykułu termin „,demon” będzie stosowany zamiennie z określeniem ,zły duch” lub „złe duchy”.

${ }^{28}$ Por. Clemens Alexandrinus, Protrepticus III 43, 1, ed. C. Mondésert, SCh 2, Paris 1949, 102, tłum. J. Sołowianiuk: Klemens Aleksandryjski, Zachęta Greków, PSP 44, 146.

${ }^{29}$ Por. Tertullianus, Apologeticum XXVII 4, CCL 1, 139, POK 20, 130.

${ }^{30}$ Por. Minucius Felix, Octavius 26, 8, PL 3, 335, PSP 44, 59; Witczyk, Opętanie, s. 37.

${ }^{31}$ Por. Tertullianus, Apologeticum XXII 4, CCL 1, 128, POK 20, 105.

${ }^{32}$ Por. Origenes, Contra Celsum VIII 36, SCh 150, 252-254, thum. Kalinkowski, s. 402.

${ }^{33}$ Por. Iustinus, Apologia II 4(5), 4, SCh 507, 330, BOK 24, 275; Tertullianus, Apologeticum XXIII 4, CCL 1, 131, POK 20, 111.

${ }^{34}$ Por. Tertullianus, Apologeticum XXII 4-5, CCL 1, 128-129, POK 20, 105; Origenes, Contra Celsum I 31, SCh 132, 160, thum. Kalinkowski, s. 57.

${ }^{35}$ Por. Tatianus, Oratio ad Graecos 18, PG 6, 848, BOK 24, 332.

${ }^{36}$ Por. Minucius Felix, Octavius 27, 2, PL 3, 338, PSP 44, 61; Tatianus, Oratio ad Graecos 18, PG 6, 848, BOK 24, 332.

${ }^{37}$ Por. Minucius Felix, Octavius 27, 7, PL 3, 339, PSP 44, 61. W związku z tym R. Garrigou-Lagrange (Trzy okresy życia wewnętrznego, s. 894) pisze: „Przez opętanie szatan mieszka rzeczywiście w ciele człowieka, zamiast tylko dać mu odczuć swoje działanie od zewnątrz, jak w obsesji. Poza tym, działając wewnątrz, nie tylko przeszkadza on swobodnemu użyciu władz człowieka, lecz sam mówi i działa przez narządy opętanego, tak, że ten nie może temu przeszkodzić, a nawet na ogół bez jego wiedzy". 
ciała niczym złodzieje swą zdobycz, wywołują w nich określone, zamierzone przez siebie skutki, które nazywa chorobą (vó oos), po czym przywracają chorych do poprzedniego stanu ${ }^{38}$. Nie jest jednak jasne, czy zniszczenie choroby, jaką same demony wywołały, rozumie on jako definitywne opuszczenie przez nich ludzkiego ciała, czy też byłoby to jedynie ukrycie widocznych skutków ich obecności ${ }^{39}$.

Chociaż opanowanie ciała przez złe duchy wywołuje niewątpliwie cierpienie poddanych ich wpływom ludzi, to jednak apologeci oceniają jako znacznie ważniejsze zniewolenie duszy. Nie sprecyzują jednak na czym to zjawisko polega oraz czy jest ono równoznaczne $\mathrm{z}$ opanowaniem przez demony ludzkiego ciała. Tertulian podkreślając bowiem, że złe duchy mogą zaatakować zarówno ciało jak i duszę człowieka, zaznacza, że przede wszystkim prowadzą one człowieka do bałwochwalstwa ${ }^{40}$. W tym kontekście zniewolenie duszy nie oznaczałoby zapanowania demonów nad nią, lecz raczej skłonienie jej do wyboru zła i uwikłanie jej w grzech, zaś bezpośrednie oddziaływanie złego ducha mogłoby dotyczyć jedynie umysłu, czy też sfery sensualno-emocjonalnej (np. wzbudzanie namiętności, strachu) ${ }^{41}$. Podobną opinię wyraża również Orygenes, który naucza, że Bóg pozostawia człowieka uwikłanego z własnej woli w praktyki magiczne złym duchom, skutkiem czego jest on przez nie dręczony niechcianymi myślami, podpowiadanymi przez demona, albo innymi nieszczęściami ${ }^{42}$. Owo pozostawienie człowieka wiąże się z wyborem przez niego drogi bezbożności, dlatego też twierdzenie o zawładnięciu przez złe duchy ludzkimi duszami odnosi Aleksandryjczyk do wszystkich żyjących

${ }^{38}$ Por. Tatianus, Oratio ad Graecos 18, PG 6, 848, BOK 24, 332.

${ }^{39} \mathrm{~W}$ świetle nauki Tacjana możliwe są obie interpretacje. $\mathrm{Z}$ jednej strony pisze on bowiem o tym, że demony opuszczają chorych (tamże 18, PG 6, 848, BOK 24, 332), natomiast w innym miejscu (tamże 16, PG 6, 841, BOK 24, 329) podkreśla, że kiedy atakują one ciało szaleństwem, uciekają dopiero wówczas, gdy zostają przepędzenie mocą słowa Bożego.

${ }^{40}$ Por. Tertullianus, Apologeticum XXII 5-6, CCL 1, 129, POK 20, 105-106.

${ }^{41}$ Poglądy Tertuliana na temat możliwości zniewolenia duszy należy rozważać w kontekście jego antropologii, w ramach której autor Apologetyku podkreśla ścisłe złączenie ciała i duszy w człowieku. Dotyczy ono również sfery nadprzyrodzonej, ponieważ dusza doznaje łaski Bożej wówczas, gdy ciało jest obmywane wodą chrztu i kiedy żywi się ono Ciałem i Krwią Chrystusa (por. Tertullianus, De resurrectione carnis 7, 9 - 8, 3, ed. J.G.P. Borleffs, CCL 2, Turnhout 1954, 930931). Oznacz to - jak podkreśla M. Szram (Ciało zmartwychwstałe w myśli patrystycznej przełomu II i III wieku, Lublin 2010, 245) - że zarówno ciało jak i dusza są wspólnie odpowiedzialne za dobre i złe uczynki, chociaż przyczyna każdego grzechu ma swoje źródło w duszy w postaci dobrowolnego namysłu, a ciało jedynie wypełnia uczynkiem podjętą decyzję. W tym kontekście może Tertulian mówić o zniewoleniu ciała i duszy, gdyż oddziaływanie diabelskie dotyczyłoby całego człowieka. Niemniej jednak nie oznacza to opanowania ludzkiej duszy rozumianej w sensie substancjalnym w taki sposób, by demony mogły nią kierować według własnej woli. Szerzej na temat ciała i duszy w nauce Tertuliana zob. Szram, Ciało zmartwychwstałe, s. 236-255.

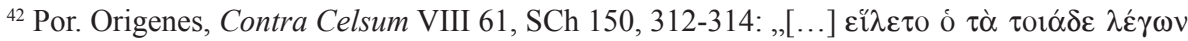

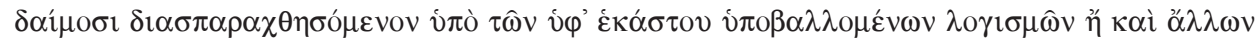

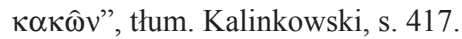


na ziemi i umieszcza je w kontekście odkupieńczej śmierci Jezusa ${ }^{43}$. Można więc uznać, że chodzi tu przede wszystkim o zniewolenie duszy przez grzech, co wyjaśnia on odwołując się do obrazu okrycia umysłu ludzkiego ciemno-

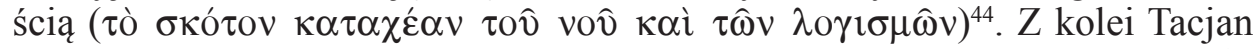
Syryjczyk, choć stwierdza, że demony atakują szatę ciała burzą szaleństwa ${ }^{45}$, to równocześnie podkreśla, że ich głównym celem jest deprawacja ludzkiego umysłu i skierowanie go w stronę rzeczy ziemskich ${ }^{46}$. Wydaje się zatem, że trafnie istotę zniewolenia duszy oddaje Justyn, który naucza o niej w następujących słowach:

„Na niczym innym nie zależy bowiem tak bardzo owym demonom, jak na oderwaniu ludzi od Boga, Stwórcy [wszystkiego], i Chrystusa, Jego pierworodnego Syna. Tych, którzy nie są zdolni wznieść się ponad ziemię, przywiązali i ciągle coraz silniej przywiązują do rzeczy ziemskich i dzieł rąk ludzkich, do tych zaś, którzy kontemplują rzeczywistości boskie, zbliżają się podstępnie i jeśli nie kierują się oni zdrowym rozsądkiem ani nie prowadzą czystego, wolnego od namiętności życia, wpędzają ich w bezbożność" ${ }^{47}$.

W świetle powyższych świadectw apologetów należałoby uznać, że opętanie w sensie ścisłym dotyczy jedynie ciała człowieka, bo nad nim demony potrafią zapanować i z niego mogą być wypędzane ${ }^{48}$, natomiast w sensie szerszym należałoby je rozumieć jako stan zniewolenia umysłów ludzkich wyrażający się najpełniej w chorobie bezbożności ${ }^{49}$.

Głównym celem działania demonów jest więc skłonienie ludzi, by nie zabiegali o własne zbawienie ${ }^{50}$, przeszkadzanie im w prowadzeniu cnotliwego życia ${ }^{51}$, oszukiwanie ich i wprowadzanie w błąd, by w konsekwencji odwrócili się od prawdziwego Boga. Wszyscy ci, którzy pozwalają się uwieść złym

${ }^{43}$ Por. tamże I 31, SCh 132, 159-160, thum. Kalinkowski, s. 57.

${ }^{44}$ Por. tamże VII 4, SCh 132, 18-20, tłum. Kalinkowski, s. 342; Clemens Alexandrinus, Protrepticus XI 111, 1, SCh 2, 179, PSP 44, 194.

${ }^{45}$ Por. Tatianus, Oratio ad Graecos 16, PG 6, 841, BOK 24, 329.

${ }^{46}$ Por. tamże 16, PG 6, 840-841, BOK 24, 329.

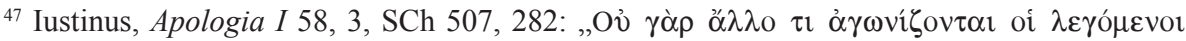

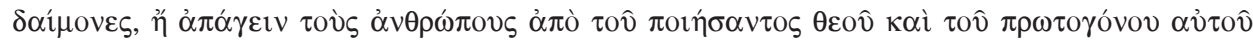

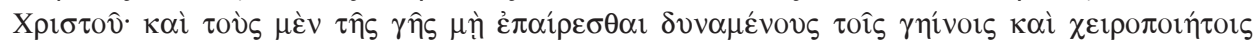

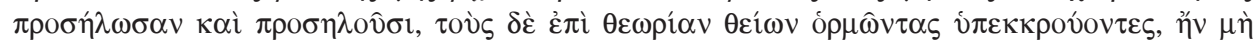

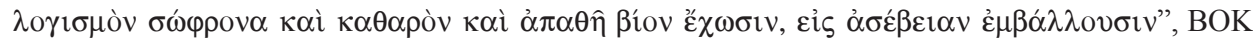
$24,249$.

${ }^{48}$ Por. Minucius Felix, Octavius 27, 5, PL 3, 339, PSP 44, 61; Garrigou-Lagrange, Trzy okresy życia wewnętrznego, s. 894.

${ }^{49}$ Por. Pałucki, Chrystus Boski Lekarz, s. 16-18; T. Kaczmarek, Zło o charakterze osobowym - szatan w refleksji teologicznej i doświadczeniu Kościoła, w: Egzorcyzmy dawniej i dziś. W blasku Chrystusa i cieniu szatana, red. B. Bartkowski - A. Posacki, Warszawa 2004, 35-37.

${ }^{50}$ Por. Iustinus, Apologia I 14, 1, SCh 507, 162, BOK 24, 215-216; J.N.D. Kelly, Początki doktryny chrześcijańskiej, tłum. J. Mrukówna, Warszawa 1988, 131.

${ }^{51}$ Por. Origenes, Contra Celsum VII 3, SCh 150, 18-20, thum. Kalinkowski, s. 342. 
duchom zostają pogrążeni w ciemnościach umysłu, tracąc tym samym sprzed oczu Bożą światłość. Konsekwencją tego jest nieznajomość Boga i związane $\mathrm{z}$ nią zwrócenie się $\mathrm{w}$ stronę rzeczy ziemskich, a także związane $\mathrm{z}$ tym zniekształcenie prawdy o człowieku i świecie przyrody ${ }^{52}$. Wskutek tego demony, pogrążywszy uwiedzione przez siebie dusze w ciemnościach i nieprawościach, pozostawiają je ich własnym wyobrażeniom $\left(\varphi \alpha \nu \tau \alpha \sigma^{\prime} \alpha\right)$ o Bogu i człowieku, które $\mathrm{w}$ istocie są niewiedzą (ó $\gamma v 01 \alpha)^{53}$ dotyczącą obu tych rzeczywistości. Działanie to opisuje autor Oktawiusza w następujących słowach:

„Istnieją błąkające się duchy nieczyste, w których niebiańską moc przydusiły ziemskie upadki i pożądliwości. Te więc duchy obciążone występkami i całkowicie $\mathrm{w}$ nich pogrążone, skoro już zatraciły należną im $\mathrm{z}$ istoty nieskalaność, szukając pocieszy w swoim upadku zaczynają, same zatracone, wodzić innych na zatracenie, same sprowadzone z właściwej drogi, sprowadzają z niej też innych i same od Boga oderwane, drugich od Niego odrywają, a czynią to poprzez nakłanianie do uczestniczenia w fałszywych kultach religijnych" ${ }^{4}$.

W świetle powyższych uwag można jednak zauważyć, że skoro demony usiłują sprowadzić człowieka na drogę bezbożności i skłaniają go do zła, to znaczy to, że nie jest on bezwolnym bytem zdanym na samowolę złych duchów. Zawsze bowiem może nie ulec ich namowom, choć - jak się wydaje im bardziej pozostaje pogrążony w mroku błędu, tym mniejsze jest prawdopodobieństwo, by samodzielnie dotarł do Bożego światła i wyrwał się z niewoli. Niemniej jednak sama szkodliwa działalność demonów nie wyjaśnia w pełni możliwości opętania, gdyż potrzebne jest jeszcze do tego otwarcie złym duchom drzwi do ludzkiej duszy (a w związku z tym również ciała) przez samego człowieka. Rzeczą konieczną wydaje się zatem postawienie pytania: jakimi ścieżkami mogą demony docierać do ludzi i na jakiej drodze, zdaniem apologetów wczesnochrześcijańskich, możliwe jest zaistnienie opętania?

${ }^{52}$ Por. tamże VI 66, ed. M. Borret, SCh 147, Paris 1969, 344, thum. Kalinkowski, s. 329; tamże IV 31, SCh 136, 260-262, tłum. Kalinkowski, s. 203; W. Myszor, Pierwotne chrześcijaństwo wobec pluralizmu świata antycznego, w: Kościól, świat i zbawienie we wczesnym chrześcijaństwie, Warszawa 2004 = SACh 17 (2004) 11-15; T. Špidlík - I. Gargano - V. Grossi, Duchowość Ojców Kościoła, thum. K. Franczyk - J. Serafin, III, Kraków 2004, 110-112.

${ }^{53}$ Por. Tatianus, Oratio ad Graecos 14, PG 6, 836, BOK 24, 326; T. Kołosowski, Krytyka politeizmu i kultów pogańskich w pismach apologetów II w., w: Wczesne chrześcijaństwo a religie, red. I.S. Ledwoń - M. Szram, Lublin 2012, 108-115.

${ }^{54}$ Minucius Felix, Octavius 26, 8, PL 3, 335: „Spiritus sunt insinceri, vagi, a coelesti vigore terrenis labibus et cupiditatibus degrevati. Isti igitur spiritus posteaquam simplicitatem substantiae suae, onusti et immersi vitiis, perdiderunt, ad solatium calamitatis suae non desinunt perditi iam perdere, et depravati errorem pravitatis infundere, et alienatia Deo, inductis pravis religionibus a Deo segregare", PSP 44, 59. Por. Athenagoras, Supplicatio pro christianis 26, 1-5, ed. B. Pouderon, SCh 379, Paris 1992, 171-173, tłum. S. Kalinkowski: Atenagoras z Aten, Prośba za chrześcijanami, Warszawa 1985, 65-66. 
3. Na drodze do opętania. Wprawdzie bez-bożność jako życie bez Boga posiada wiele wymiarów i może być rozważana na poziomie intelektualnym lub moralnym ${ }^{55}$, to jednak apologeci wczesnochrześcijańscy zwracają szczególną uwagę na jeden, fundamentalny jej aspekt, którym jest bałwochwalstwo. W nim bowiem człowiek najbardziej otwiera się na działanie demonów pozwalając im uwieść się i zniewolić. Tertulian uważa nawet, że jest ono głównym przestępstwem ludzkości, gdyż skupiają się w nim wszystkie pozostałe grzechy ${ }^{56}$. Bałwochwalstwo jest jednak rzeczywistością złożoną i wyraża się na dwóch podstawowych płaszczyznach. Charakteryzuje je precyzyjnie Orygenes, stwierdzając:

„Dlatego ten, kto czci Boga, nie powinien kłaniać się demonom. Natura demonów objawia się także w tym, że niektórzy ludzie wzywają je, by wzbudzały miłość lub nienawiść, albo by przeszkadzały w określonych przedsięwzięciach; postępują w ten sposób ludzie, którzy za pomocą magicznych zaklęć i czarów potrafią je przywołać i nakłonić do działania według swojej woli. Dlatego wszelki kult demonów jest obcy wyznawcom najwyższego Boga. Kult ten przejawia się również w czci oddawanej rzekomym bogom, ponieważ «wszyscy bogowie pogańscy to demony» $(\mathrm{Rz} 8,2)$. [...] Oto dlaczego unikamy demonów jak zarazy i twierdzimy, że kultem demonów są wszystkie ceremonie religijne odprawiane przez Greków przy ołtarzach, przed posągami i w świątyniach bogów"57.

Owo otwarcie drzwi demonom dokonuje się zatem poprzez kult pogańskich bóstw, wyrażający się w rozmaitych obrzędach religijnych oraz w praktykowaniu magii i czarów. Poprzez te praktyki zawiązuje się bowiem więź pomiędzy ludźmi, którzy je stosują a złymi duchami skrywającymi się za pogańskimi rytuałami. Tacjan zauważa, że nawet ten, kto kieruje się dobrymi intencjami i sam nie jest zły, lecz ma jakiś związek ze złem, choćby dla czynienia dobra, staje się niewolnikiem zła ze względu na udział w tym samym przedmiocie, w jakim uczestniczą demony ${ }^{58}$. Więź ze złym i przebywanie $\mathrm{w}$ tego

${ }_{55}^{5}$ Por. Iustinus, Apologia II 4(5), 4, SCh 507, 330, BOK 24, 275.

${ }^{56}$ Por. Tertullianus, De idolatria I 1 - III, 3, ed. A. Reifferscheid - G. Wissowa, CCL 2, Turnhout 1954, 1101-1103, thum. K. Obrycki: Tertulian, O batwochwalstwie, w: Tertulian, Wybór pism, III, PSP 65, Warszawa 2007, 127-129.

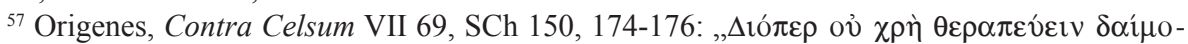

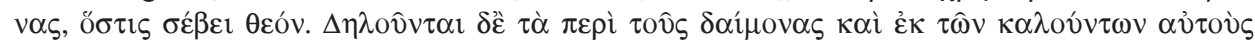

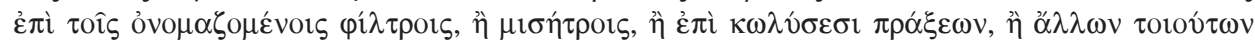

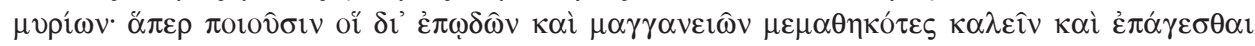

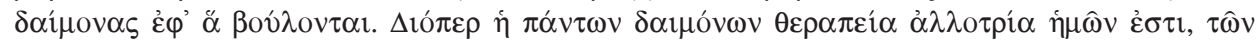

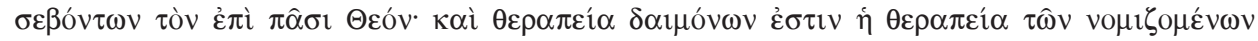

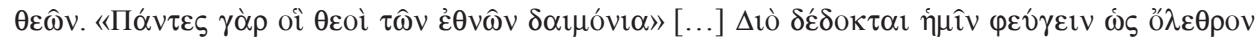

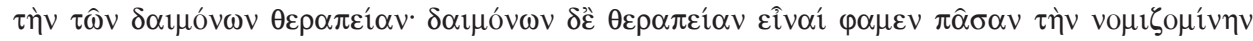

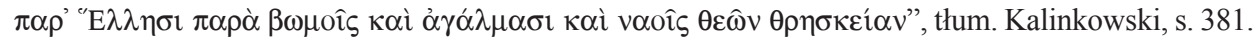

${ }^{58}$ Por. Tatianus, Oratio ad Graecos 18, PG 6, 845, BOK 24, 331. 
rodzaju środowisku zawsze deprawuje. Wszelki kult pogański jest zatem dla chrześcijan równoznaczny z kultem demonów, które podają się za bogów i żądają, by składano im ofiary ${ }^{59}$. One również, posługując się stworzoną przez Boga materią, wykorzystują ją do złych celów zniewalając ludzi w rozmaitych obrzędach magicznych ${ }^{60}$. Dlatego też taka forma religijności jest określana mianem zabobonu, za pomocą którego demony związują ludzi ze sobą ${ }^{61}$.

Spośród rożnych form i praktyk magicznych stosowanych przez pogan, apologeci wymieniają przede wszystkim, szczególnie popularną wśród współczesnych im obywateli Imperium Romanum, sztukę wróżbiarską. Minucjusz Feliks podkreśla, że źródłem natchnienia oraz przyczyną skuteczności przepowiadania wieszczów są demony, które w ten sposób oszukują człowieka i utwierdzają go w błędzie idolatrii ${ }^{62}$. Klemens z Aleksandrii podaje sposoby uprawiania wróżb, które polegają głównie na wywoływania duchów i nazywa je bezbożnymi praktykami $^{63}$. Potwierdzenie tego świadectwa znajduje się również w tekstach Justyna oraz Tertuliana. Piszą oni bowiem o takich obrzędach magicznych, w których magowie wykorzystują do uprawiania wróżb wywoływane przez siebie dusze zmarłych. W ten sposób pozyskują sobie demony i dzięki ich pomocy oszukują ludzi podając się za proroków przekazujących boskie słowa ${ }^{64}$. Orygenes z kolei uważa, iż złe duchy przywabiane przez magów za pomocą specjalnie wypracowanych formuł są im posłuszne po to, by pod pozorem dobra zwodzić uczniów Chrystusa i pogrążać ich w nieprawości. Ceną za owo posłuszeństwo i związaną z nim skuteczność zaklęć jest jednak zbawienie ludzkiej duszy ${ }^{65}$.

${ }^{59}$ Por. Iustinus, Apologia I 12, 5 SCh 507, 154-156, BOK 24, 214; Athenagoras, Supplicatio pro christianis 18, 1-6, SCh 379, 127-130, tłum. Kalinkowski, s. 48-50. Szerzej na temat patrystycznych koncepcji pochodzenia bogów pogańskich zob. Kołosowski, Krytyka politeizmu, s. 108-115.

${ }^{60}$ Por. Tatianus, Oratio ad Graecos 17, PG 6, 844, BOK 24, 330. A. Wypustek (Rola oskarżenie o magię $i$ wróżbiarstwo w prześladowaniu chrześcijan na przełomie II i III wieku, VoxP 17 (1997) t. 32-33, 45-60) zwraca uwagę, że stosunek obywateli Cesarstwa Rzymskiego, a szczególnie jego władców, do magii nie był jednoznaczny. Chociaż bowiem praktyki magiczne były szeroko stosowane, to jednak władcy usiłowali je wytępić, uważając je za niebezpieczne, zwłaszcza jeśli dotyczyły sfery polityki. Dlatego też jednym z zarzutów kierowanych wobec chrześcijan było oskarżanie ich o praktykowanie magii. Więcej o praktykach magicznych świata starożytnego zob. H.P. Hasenfratz, Religie świata starożytnego a chrześcijaństwo, tłum. U. Poprawska, Kraków 2006, 80-100; P. Wygralak, Stanowisko Ojców Kościoła wobec magii, w: Wczesne chrześcijaństwo a religie, s. 256-261; tenże, Stanowisko Kościoła wobec idolatrii i magii, s. 71-134.

${ }^{61}$ Por. Clemens Alexandrinus, Protrepticus IV 47, 5, SCh 2, 108, PSP 44, 122; tenże, Stromata VII 22, 1 - 27, 6 ed. A. Le Boulluec, SCh 428, Paris 1997, 91-104, tłum. J. Niemirska-Pliszczyńska: Klemens Aleksandryjski, Kobierce, II, Warszawa 1994, 233-237; A. Posacki, Encyklopedia zagrożeń duchowych. Mistyka, ezoteryzm, okultyzm, II, Radom 2009, 178; M.P. Nilsson, Geschichte der griechischen Religion, II, München 1974, 529.

${ }^{62}$ Por. Minucius Felix, Octavius 27, 1-2, PL 3, 336-338, PSP 44, 60-61.

${ }^{63}$ Por. Clemens Alexsandrinus, Protrepticus II 11, 1-3, SCh 2, 67-68, PSP 44, 124-125.

${ }^{64}$ Por. Tertullianus, Apologeticum XXII 8 - XXIII 1, CCL 1, 129-130, POK 20, 106-110; Iustinus, Apologia I 18, 3-5, SCh 507, BOK 24, 220.

${ }^{65}$ Por. Origenes, Contra Celsum II 50-51, SCh 132, 398-406, thum. Kalinkowski, s. 121-122. 
Formę zabobonu bałwochwalstwa stanowią również inne praktyki, za pomocą których człowiek pragnie zapewnić sobie szczęście w życiu oraz zdrowie ciała. Należą do nich m.in. noszenie amuletów, śpiewanie czarodziejskich pieśni mających przynieść ratunek z nieszczęścia ${ }^{66}$, związane z magicznym praktykami posługiwanie się różnego rodzaju korzeniami i roślinami, które mają przynosić uzdrowienie, wzbudzić uczucie miłości lub nienawiści, czy też dopomóc $\mathrm{w}$ zemście ${ }^{67}$. Za naganne dla chrześcijanina uważają apologeci również wiarę w astrologię, gdyż jest ona rodzajem bałwochwalstwa, a za znakami zodiaku i horoskopami, tak jak i za wszystkimi praktykami magicznymi, stoją demony ${ }^{68}$.

W celu właściwej oceny i rozeznania rozmaitych praktyk, z jakimi mogą spotkać się chrześcijanie w świecie pogańskim, Orygenes proponuje, aby zwracać uwagę przede wszystkim na skutki, jakie one wywołują w duszy zarówno uprawiającego kult obcych bóstw, jak i poddających się rytuałom magicznym. Zauważa on przy tym, iż nikt nie potrafi udowodnić, by działania magów zawróciły kogokolwiek z drogi występku i grzechu ${ }^{69}$. Co więcej, rozmaite sztuczki magiczne i fałszywe cuda odwodzą ludzi od prawdziwego Boga i utrzymują ich w błędzie idolatrii, podczas, gdy cuda dokonane mocą Bożą zawsze prowadzą ku dobru służąc zbawieniu duszy ${ }^{70}$. Odpowiadając na zarzut Celsusa, który twierdził, że Jezus posługiwał się sztuczkami magicznymi, by zdobyć i oszukać swych uczniów, Orygenes naucza:

„Istotnie, uczynki Jezusa byłyby może podobne do postępowania czarnoksiężników, gdyby Jezus dokonywał cudów jedynie po to, żeby się popisać swymi umiejętnościami, jak to robią oni. Tymczasem żaden kuglarz swymi sztuczkami nie nakłania ludzi do naprawy obyczajów, nie zwraca ku bojaźni Bożej tych, którzy zdumiewają się tym, co widzą, ani nie próbuje przekonać swych widzów, aby żyli jak ludzie, którzy w przyszłości staną przed sądem Bożym. [...] Jezus natomiast dokonywał cudów po to, aby skłonić widzów do moralnej poprawy; czyż więc nie jest rzeczą naturalną, że sam dawał przykład najdoskonalszego życia nie tylko swoim prawdziwym uczniom, ale również wszystkim pozostałym uczniom? Dla uczniów był wzorem po to, aby ich skłonić do głoszenia nauki zgodnie z wolą Bożą, dla pozostałych ludzi zaś

\footnotetext{
${ }^{66}$ Por. Clemens Aleksandrinus, Protrepticus XI 115, 2, SCh 2, 183-184, PSP 44, 196.

${ }^{67}$ Por. Tatianus, Oratio ad Graecos 17, PG 6, 841-844, BOK 24, 330; Hasenfratz, Religie świata starożytnego a chrześcijaństwo, s. 80-100.

${ }^{68}$ Por. Tertullianus, De Idolatria 9, 1-7, CCL 2, 1107-1108, PSP 65, 133-134; Tatianus, Oratio ad Graecos 9, PG 6, 825-828, BOK 24, 320-321; Origenes, In Numeros hom. 12, 4, PG 12, $665-$ 666, tłum. S. Kalinkowski: Orygenes, Homilie o Księdze Liczb, PSP 34/1, Warszawa 1986, s. 127; tamże 13, 6, PG 12, 673-674, PSP 34/1, 136; Wygralak, Stanowisko Ojców Kościoła wobec magii, s. 264; Myszor, Pierwotne chrześcijaństwo wobec pluralizmu świata antycznego, s. 14; A. Posacki, Wybrane problemy z dziedziny okultyzmu, w: Egzorcyzmy dawniej i dziś, s. 49-66.

${ }^{69}$ Por. Origenes, Contra Celsum II 44, SCh 132, 384-386, tłum. Kalinkowski, s. 116.

${ }^{70}$ Por. tamże II 51-52, SCh 132, 402-408, thum. Kalinkowski, s. 121-122.
} 
w tym celu, aby z Jego słów, uczynków i cudów nauczyli się, jak mają żyć i całym swym postępowaniem starali się przypodobać najwyższemu Bogu"’1.

Dlatego też Aleksandryjczyk zaleca chrześcijanom, by uważnie przyglądali się życiu i obyczajom tych, którzy obiecują im dokonywanie jakichkolwiek cudów ${ }^{72}$, zaś Tertulian przypomina, że wszystkie tego rodzaju sztuki, za którymi stoją demony poprzez ich związek z jakąkolwiek postacią idolatrii, są surowo zakazane przez Boga i żaden chrześcijanin nie może posługiwać się nimi nawet do celów prywatnych (suae causae) ${ }^{73}$. Chrześcijanin powinien zatem unikać ich także wówczas, gdy obiecują jakieś dobra doczesne. Orygenes pisze w związku z tym:

„Gdybyśmy więc mieli osiągnąć zdrowie i szczęście w życiu przez oddawanie czci demonom, wolelibyśmy raczej chorować i być nieszczęśliwi, ale mieć świadomość czystej pobożności wobec Boga wszechrzeczy, niż być zdrowi i żyć w najwyższym szczęściu doczesnym, ale odłączyć się od Boga i odrzucić Go, a przez to chorować na duszy i w duszy być nieszczęśliwymi"774.

Kryterium rozstrzygającym o wartości magii oraz wszelkich praktyk służących zapewnieniu sobie zdrowia i doczesnego powodzenia nie jest więc ich

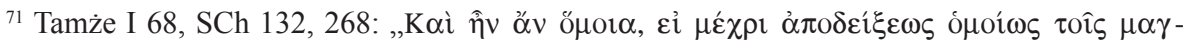

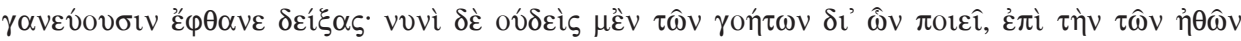

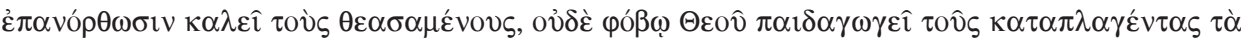

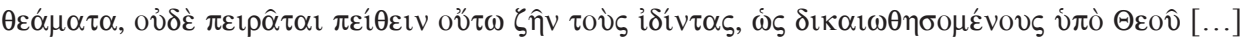

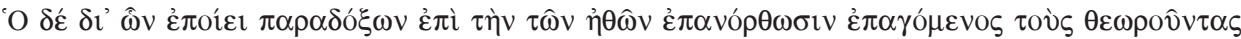

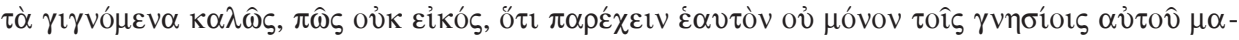

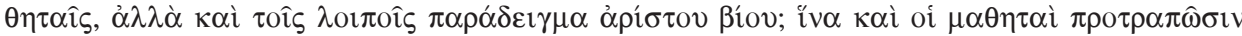

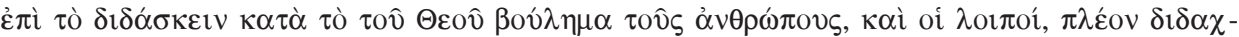

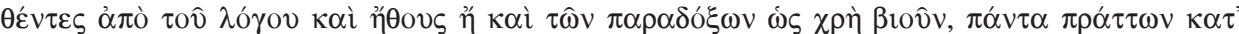

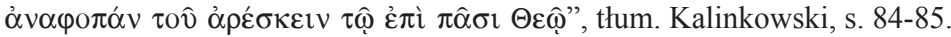

${ }^{72}$ Por. tamże II 51-52, SCh 132, 402-408, tłum. Kalinkowski, s. 121-122.

${ }^{73}$ Por. Tertullianus, Apologeticum XXXV 12, CCL 1, 146-147, POK 20, 148-149. Dlatego też chrześcijanie w swym codziennym życiu skazani byli na pewnego rodzaju rozdarcie, gdyż usiłowali żyć jak inni ludzie, ale jednocześnie unikać niebezpieczeństwa idolatrii, por. J. Daniélou - H.I. Marrou, Historia Kościoła, I, tłum. M. Tarnowska, Warszawa 1986, 142-148. Problem ten istniał także w późniejszych wiekach. Na temat pasterskiej działalności Kościoła odnośnie do magii i bałwochwalstwa, zob. P. Szczur, Problematyka społeczna w późnoantycznej Antiochii na podstawie nauczania homiletycznego Jana Chryzostoma, Lublin 2008, 530-542; Wygralak, Stanowisko Ojców Kościoła wobec magii, s. 265-271; tenże, Stanowisko Kościoła wobec idolatrii i magii, s. 222-298; I. Milewski, Obyczaje życia codziennego chrześcijan drugiej połowy IV wieku w świetle pism Bazylego Wielkiego, VoxP 17 (1997) t. 32-33, 101-112.

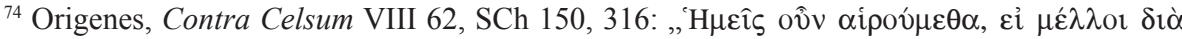

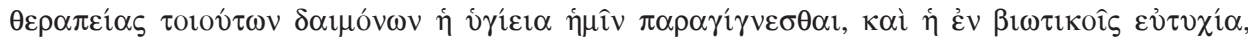

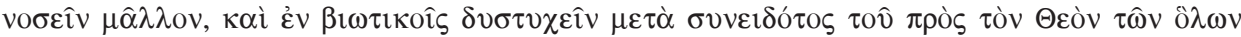

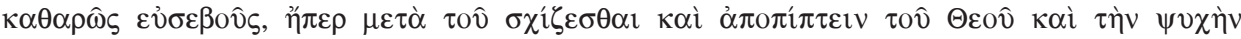

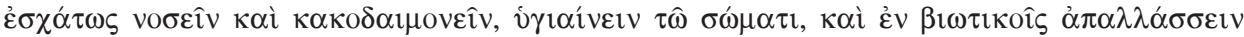

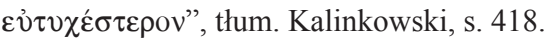


skuteczność, której chrześcijanie nie kwestionują ${ }^{75}$, lecz dobro duchowe lub jego brak ${ }^{76}$. Skutki te nie są jednak widoczne od razu i często zdarza się tak, iż dopiero dalekie odejście od Boga i zniewolenie człowieka pozwala je zauważyć. Stąd też świadectwa apologetów wczesnochrześcijańskich wskazują również na fakt, że wiedzę o szkodliwym działaniu kultycznych praktyk pogańskich chrześcijanie czerpią często nie tylko z rozważań teologicznych, lecz także z doświadczenia egzorcyzmów, w których uczestniczą. One właśnie są lekarstwem, jakie Kościół podaje opętanym przez demony ludziom7 ${ }^{77}$

\section{EGZORCYZMY W ŚWIADECTWIE APOLOGETÓW}

Chociaż apologie wczesnochrześcijańskie nie są traktatami o egzorcyzmach, to jednak na marginesie polemiki (dialogu) z kulturą antyczną podejmują tę problematykę dając świadectwo zastanej już i ugruntowanej praktyki Kościoła. Apologeci zaliczają bowiem egzorcyzmy do zwyczajnej, nie wywołującej u chrześcijan żadnego zdziwienia, działalności duszpasterskiej. Co więcej, często owa praktyka pełni w apologiach funkcję argumentu na rzecz prawdziwości nauki Ewangelii oraz wyższości chrześcijaństwa nad religią pogańską ${ }^{78}$. Jest ona opisywana bądź to jako wypędzanie złego ducha, który w jakiś sposób zawładnął człowiekiem i zniewolił go, bądź też jako proces leczenia $z$ choroby opętania ${ }^{79}$. Wobec tego należy zapytać o to, jak widzieli to zjawisko apologeci? oraz określić warunki możliwości i skuteczności tej praktyki.

1. Fenomen egzorcyzmów. W apologiach wczesnochrześcijańskich nie zapisano przebiegu obrzędu egzorcyzmów. Zawierają one jedynie świadectwa takiej praktyki Kościoła. Dlatego też szczególnie interesująca dla choćby szczątkowego jej objaśnienia wydaje się być relacja odnotowana w Oktawiuszu. Autor opisuje egzorcyzmy zwracając się do pogan w następujących słowach:

${ }^{75}$ Por. tamże I 25, SCh 132, 140-144, thum. Kalinkowski, s. 53.

${ }^{76}$ Por. Tertullianus, Apologeticum XXI 31, CCL 1, 128, POK 20, 102; M. Terka, Magia w Biblii i u Ojców Kościoła, w: Magia - cała prawda, red. M. Piotrowski, Poznań 2010, 35-39. Rzeczywistą chorobą jest bowiem zniewolenie człowieka przez demony, którym on oddaje boską cześć, a nie jakiekolwiek nieszczęście w życiu doczesnym, zob. Origenes, Contra Celsum VIII 62, SCh 150, 316, tłum. Kalinkowski, s. 418.

${ }_{77}$ Por. Wygralak, Stanowisko Kościoła wobec idolatrii i magii, s. 216-222.

${ }^{78}$ Por. Tertullianus, Apologeticum XXIII 1-19, CCL 1, 130-133, POK 20, 109-116.

${ }^{79}$ Por. Tatianus, Oratio ad Graecos 16, PG 6, 841, BOK 24, 329. Apologeci nie precyzują jednak tego kogo dotyczą egzorcyzmy: czy są one stosowane wobec ludzi znajdujących się poza Kościołem lub wyłącznie w stosunku do nawróconych pogan, przygotowujących się do przyjęcia chrztu świętego, czy też odnoszą się może do chrześcijan, którzy popadli w grzech idolatrii należąc już do Kościoła, ale pragną powrócić do jedności z nim. Dla problematyki egzorcyzmów nie ma to jednak większego znaczenia, gdyż nie zmienia w niczym istoty tej kościelnej praktyki. 
„Większość z was wie, że same demony rozgłaszają o sobie te historie ilekroć tylko uda się nam je wypędzić z jakiegoś ciała dzięki mocy egzorcystów albo też przez żarliwą modlitwę. Sam Saturn, Serapis, Jowisz i jakie tam demony jeszcze czcicie, złamani bólem ujawniają kim są, zwłaszcza, że w obecności niektórych z was nie chcą ściągać na siebie hańby kłamstwa. Wierzcie im, gdy dają o sobie świadectwo, że są demonami. Przebywają w ludzkich ciałach albo nagle, albo wbrew woli z nich uciekają, albo też tracą z wolna swą moc, a dzieje się tak, gdy usłyszą przeszywający je strachem dźwięk imienia Boga jedynego i prawdziwego. Zależy to od siły wiary cierpiącego, jak i od łaski uzdrawiającego" $"$.

Z tego świadectwa wyłania się obraz walki duchowej prowadzonej z demonami przez ludzi, którzy w imieniu Boga zmuszają złego ducha, wbrew jego woli, a nawet przy pewnym oporze z jego strony, do opuszczenia ciała ludzkiego. Stąd też pełne uwolnienie człowieka może nastąpić od razu lub stanowić bliżej nieokreślony temporalnie proces. W czasie jego trwania ma miejsce szczególna manifestacja złego ducha, który zmuszony mocą Bożą, ujawnia nie tylko swoją obecność, lecz także odsłania swe prawdziwe oblicze demaskując własne kłamstwa.

Relację Minucjusza Feliksa potwierdza w tym względzie Tertulian ${ }^{81}$. Podkreśla on, że w czasie modlitwy o uwolnienie chrześcijanie wypowiadają nad opętanymi imię Chrystusa, zwracają się do demonów przypominając im Jego zwycięstwo nad nimi oraz karę wiecznego potępienia, na jaką zostaną skazani wyrokiem sądu Bożego. Złamane rozkazem Chrystusa oraz obecnością chrześcijan, pod ich tchnieniem (afflatu nostro) wychodzą one z ciał ludzi opętanych, choć - jak podkreśla Tertulian - bardzo niechętnie, cierpiące i zawstydzone tym, że zostały zdemaskowane ${ }^{82}$.

Ten opór demonów jest rzeczą powszechnie spotykaną podczas egzorcyzmów. Tertulian stwierdza, że usiłują one wszelkimi sposobami bronić się przed wyrzuceniem ich z ludzkiego ciała, a powodowane strachem, wzbudzają nienawiść nie tylko przeciw egzorcystom, ale również wobec wszystkich chrześcijan, podburzając przeciw nim pogan i stojąc w ten sposób za prześladowaniami Kościoła. Zachowują się więc jak niewolnik, który bojąc

${ }^{80}$ Minucius Felix, Octavius 27, 5-7, PL 3, 339-340: „Haec omnia sciunt plerique pars vestrum, ipsos daemonas de semetipsis confiteri, quoties a nobis et tormentis verborum et orationis incendiis de corporibus exiguntur. Ipse Saturnus, et Serapis, et Iuppiter, et quidquid daemonum colitis, victi dolore, quod sunt eloquuntur: nec utique in turpitudinem sui, nonnullis praesertim vestrum assistentibus, mentiuntur. Ipsis testibus, esse eos daemonas, de se verum confitentibus credere. Adiurati enim per Deum verum et solum, inviti miseris corporibus inhorrescunt: et vel exsiliunt statim, vel evanescunt gradatim, prout fides patientis adiuvat, aut gratia curantis aspirat”, PSP 44, 61. Por. Kołosowski, Krytyka politeizmu, s. 108-112.

${ }^{81}$ Por. Tertullianus, Apologeticum XXIII 4, CCL 1, 131, POK 20, 111.

${ }^{82}$ Por. tamże XXIII 15-16, CCL 1, 132-133, POK 20, 115. Zob. Zalewski, Walka z osobowym złem, s. 194. 
się swego pana, a wiedząc o nieuniknionej karze, na jaką został przez niego skazany, stara się z nienawiścią zaszkodzić mu dopóki ma taką możliwość. Skoro jednak demony spostrzegą, że wbrew ich wysiłkom zostają związane modlitwą egzorcyzmu, błagają tych, których do tej pory zwalczali, o zwłokę w karze, która została na nich nałożona mocą Boskiego wyroku ${ }^{83}$.

Orygenes przytacza jedną z formuł, której - jak stwierdza - skutecznie używają przeciwko demonom nie tylko chrześcijanie, ale również magowie Egipscy. Jest ona właściwie tylko przywołaniem imienia Bożego: „Boże Izraela, Boże Hebrajczyków, Boże, który strąciłeś w Morze Czerwone faraona i Egipcjan" ${ }^{84}$. Zawiera ona przypomnienie o zwycięstwie Boga nad przeciwnikiem Narodu Wybranego, co harmonizuje z przekazami Tertuliana i Minucjusza Feliksa, podobnie jak uwaga o odczytywaniu Ewangelii w czasie modlitw o uwolnienie oraz o skuteczności słowa Bożego w procesie wypędzania demonów ${ }^{85}$.

W tej walce duchowej, jaką stanowią egzorcyzmy, niezwykle istotny okazuje się czynnik Boski, który chrześcijanie wielokrotnie przywołują. Zwycięstwo człowieka nad demonem jest bowiem możliwe tylko przy wsparciu z nieba. Dlatego też należy przybliżyć owo współdziałanie Chrystusa i Jego uczniów w dziele uwolnienia opętanych.

2. Moc Imienia Bożego. Egzorcyzm jest przede wszystkim modlitwą skierowaną do Boga o wybawienie człowieka zniewolonego przez złe duchy i jako taki nie tylko jest miejscem manifestacji zła, lecz przede wszystkim objawieniem mocy Bożej. Świadectwa apologetów dowodzą, że demony właśnie ze względu na autorytet Boga, który stoi za modlącym się uczniem Chrystusa, boją się chrześcijan i są posłuszne ich rozkazom. Dlatego też Tertulian stwierdza:

„Tymczasem cała nasza nad nimi [tj. demonami] moc i potęga złączona jest z wymawianiem imienia Chrystusa i przypominaniem tego, czego od Boga oczekują, że po sądzie Chrystusa na nich spadnie. Chrystusa się bojąc w Bogu, a Boga w Chrystusie, są ulegli sługom Boga i Chrystusa" ${ }^{" 66}$.

${ }^{83}$ Por. Tertullianus, Apologeticum XXVII 4-6, CCL 1, 139, POK 20, 130-131. Możliwe, że dlatego właśnie chrześcijanie podczas modlitw o uwolnienie przypominali o ostatecznym zwycięstwie Chrystusa nad demonami oraz o wyroku potępienia, jaki spoczywa na złych duchach.

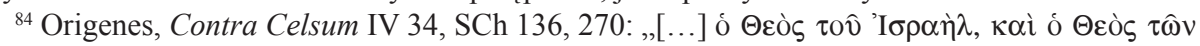

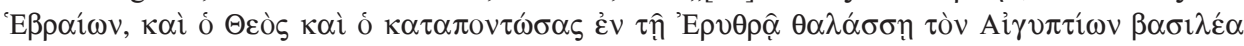

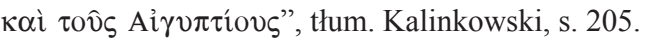

${ }^{85}$ Por. tamże I 6, SCh 132, 90, tłum. Kalinkowski, s. 39; tenże, In Numeros hom. 13, 6, PG 12 , 673-674, PSP 34/1, 136.

${ }^{86}$ Tertullianus, Apologeticum XXIII 15, CCL 1, 132-133: „Atquin omnis haec nostra in illos dominatio et potestas de nominatione Christi valet, et de commemoratione eorum, quae sibi a Deo per arbitrum Christum imminentia exspectant. Christum timentes in Deo, et Deum in Christo subiciuntur servis Dei et Christi”, POK 20, 115. 
Owo posłuszeństwo demonów jest dla Tertuliana kolejnym dowodem na to, że nie są one żadnymi bogami, gdyż jako takie nie pozwoliłyby się pokonać człowiekowi ${ }^{87}$. Justyn zaś zauważa, że żaden zaklinacz, czarodziej, czy też magik nie może uleczyć z choroby zniewolenia, a dokonują tego chrześcijanie wezwawszy imienia Jezusa Chrystusa, ukrzyżowanego za Poncjusza Piłata ${ }^{88}$.

Można przypuszczać, że z tym świadectwem Justyna zapewne nie do końca zgodziłby się Orygenes, który podkreśla moc imienia Bożego na podstawie zupełnie innych doświadczeń. Przytacza on bowiem praktykę egipskich czarowników, którzy używali jako zaklęcia imienia Boga Abrahama widząc, że dzięki temu uzyskują zamierzone przez siebie efekty ${ }^{89}$. Skuteczne uwalnianie zniewolonych ludzi nawet przez czarowników egipskich oznacza zatem, iż owo wyzwolenie nie jest dziełem ludzkim i nie dokonuje się mocą osobistej świętości egzorcysty. Istnieje tutaj jednak możliwość błędnej interpretacji samej praktyki egzorcyzmów. Skoro bowiem jej skuteczność zależy od wzywania imienia Bożego, to otwiera się możliwość potraktowania modlitwy o uwolnienie opętanych w kategoriach zwyczajnej praktyki magicznej ${ }^{90}$. Tak też - jak się wydaje - widzieli ją egipscy magowie, którzy korzystali z mocy imienia Boga Abrahama używając go jako jednego ze swych zaklęć. Dla Orygenesa prowadzącego polemikę z pogańskim filozofem Celsusem, który podnosił zarzut uprawiania magii przez Jezusa, rzeczą konieczną było przeciwstawić się temu niebezpieczeństwu ${ }^{91}$. Czyni to na dwóch płaszczyznach.

Pierwsza z nich polega na podkreśleniu, że w praktykach Jezusa i Jego uczniów na pierwszym planie jest zawsze moc Boża, gdyż jedynie ona może przezwyciężyć siłę demonów. Stąd też działanie w imię Boże jest wyższe niż jakakolwiek praktyka magiczna. Tę myśl oddaje Orygenes w następujących słowach:

„Powiem więc Grekom: magowie, którzy mają do czynienia z demonami i którzy wzywają ich zgodnie ze swymi umiejętnościami i chęcią, czynią to, dopóki nie pojawi się jakaś boska istota, silniejsza od demonów, albo nie zostanie wypowiedziane zaklęcie potężniejsze od ich zaklęć: gdy pojawi się istota boska, moc demonów ginie, ponieważ nie mogą one patrzeć na blask Majestatu Bożego"’2.

${ }^{87}$ Por. tamże XXIII 7-10, CCL 1, 131-132, POK 20, 112- 113.

${ }^{88}$ Por. Iustinus, Apologia II 5(6), 6, SCh 507, 334, BOK 24, 276; Myszor, Pierwotne chrześcijaństwo wobec pluralizmu świata antycznego, s. 17; Zalewski, Walka z osobowym złem, s. 193.

${ }^{89}$ Por. Origenes, Contra Celsum I 22, SCh 132, 130, thum. Kalinkowski, s. 50.

${ }^{90}$ To samo odnosi się również zarówno do działalności samego Jezusa, jak i do liturgii Kościoła. Por. Hasenfratz, Religie świata starożytnego a chrześcijaństwo, s. 101-107.

${ }^{91}$ Por. H. Pietras - I. Huber, Celsus i inni. Nauka i życie chrześcijan w krytyce pogańskiej II w., w: Wczesne chrześcijaństwo a religie, s. 95-96.

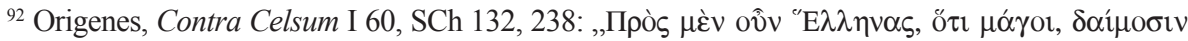

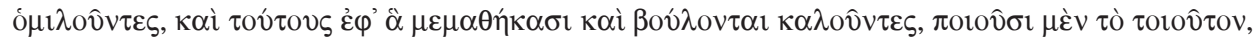

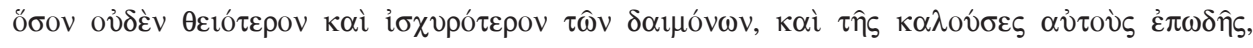


Zasadę tę ilustruje Orygenes za pomocą przykładów biblijnych. Stwierdza zatem, że kiedy narodził się Jezus i aniołowie wielbili Boga z tego powo$\mathrm{du}$, wówczas moc demonów została rozbita, a one same stały się bezsilne. W związku z tym magowie ze Wschodu, którzy oddawali się swym czarom i zaklęciom, nie mogli dzięki nim osiągać oczekiwanych skutków. Poszukując przyczyny swej niemocy, ujrzeli znak na niebie w postaci gwiazdy i zapragnęli dowiedzieć się, co on oznacza, a odkrywszy fakt przyjścia na świat zapowiadanego przez proroków człowieka, postanowili przybyć do Niego, by oddać Mu pokłon ${ }^{93}$. Również Szymon Mag usiłował oszukiwać ludzi zwodząc ich swymi magicznymi sztuczkami, jednak - jak podkreśla Orygenes - takie sposoby zdobywania zwolenników i uczniów, nie wytrzymują próby czasu. Chociaż więc niektórzy rzeczywiście dali się uwieść, to jednak w czasach współczesnych Aleksandryjczykowi jest ich już bardzo mała liczba, podczas gdy Kościół obejmuje całą ziemię ${ }^{94}$. Także znaki zdziałane przez Mojżesza w Egipcie, chociaż zewnętrznie podobne do sztuczek magów faraona, przynosiły jednak inne, pozytywne skutki. Efektem działalności Mojżesza było bowiem powstanie narodu, który został wyzwolony z niewoli i oddawał cześć jedynemu i najwyższemu Bogu, natomiast czarownicy, usiłując zwieść faraona i utrzymać Izraela w domu niewoli, ponieśli porażkę ${ }^{95}$.

Skuteczność działania magów pogańskich, którzy używają imienia Bożego, w niczym nie przeczy zatem nauce chrześcijańskiej i nie zmusza do postawienia znaku równości pomiędzy chrześcijaństwem a magią. Orygenes przypomina nawet, że sam Jezus przestrzegał swoich uczniów jedynie przez tymi, którzy będą w przyszłości podawać się za Mesjasza i czynić cuda, by w ten sposób uwiarygodnić własne kłamstwo. Natomiast, zgodnie z zapowiedzią Chrystusa, zjawią się również i tacy ludzie, którzy żyjąc w grzechu, będą w imię Jezusa czynili cuda i wypędzali złe duchy. Nie jest to jednak powód do zmartwień dla chrześcijan, gdyż świadczy to jeszcze bardziej o potędze ich Mistrza ${ }^{96}$.

Drugą płaszczyzną, na której Aleksandryjczyk wyjaśnia skuteczność wzywania imienia Bożego i broni tę praktykę przez wszelkimi konotacjami z magią, jest teoria nazw. Jest ona odpowiedzią na zarzut Celsusa sugerującego, że nie ma żadnej różnicy w tym, czy nazwie się Boga Zeusem - jak czynią to Grecy, czy też użyje się w stosunku do Niego jakiegoś innego imienia używanego przez Egipcjan lub mieszkańców Indii ${ }^{97}$.

Orygenes twierdzi natomiast, że język nie jest wynikiem umowy między ludźmi, a zatem sens nazw nie zależy od jakiejś umowy społecznej. Dlatego

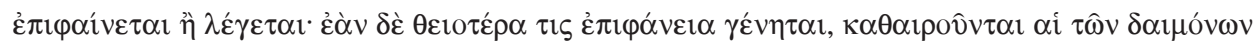

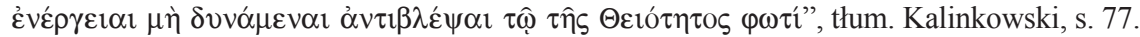

${ }^{93}$ Por. tamże, SCh 132, 238-240, thum. Kalinkowski, s. 77-78.

${ }^{94}$ Por. tamże I 57, SCh 132, 230-234, thum. Kalinkowski, s. 76.

${ }^{95}$ Por. tamże II 51-53, SCh 132, 214-222, thum. Kalinkowski, s. 212-123.

${ }^{96}$ Por. tamże II 49, SCh 132, 394-398, tłum. Kalinkowski, s. 120.

${ }^{97}$ Por. tamże I 24, SCh 132, 134-136, tłum. Kalinkowski, s. 51.
} 
też zachodzi istotna różnica pomiędzy nazwaniem Boga imieniem Jowisza, Adonai, czy Ammona ${ }^{98}$. Nie są to bowiem określenia przypadkowe, lecz jak twierdzi Aleksandryjczyk - wyrażają naukę o sprawach Bożych ${ }^{99}$ i opisują czyny, które, istoty obdarzone danym imieniem, a szczególnie byty duchowe, spełniają $\mathrm{w}$ świecie ${ }^{100}$. Teoria ta jego zdaniem dobrze wyjaśnia skuteczność zaklęć magicznych. Orygenes naucza w związku z tym:

„Dlatego właśnie owe imiona posiadają nadzwyczajną moc, jeśli wypowie się je w określonym związku; dlatego też niektóre imiona wypowiadane po egipsku pod adresem pewnych demonów, które mają władzę nad określonymi sprawami, albo po persku pod adresem innych demonów, są stosowane dla uzyskania określonych korzyści. Stanie się również jasne, że imiona demonów ziemskich, które otrzymały władzę nad pewnymi okolicami ziemi, są wypowiadane $\mathrm{w}$ języku używanym $\mathrm{w}$ danym miejscu przez mieszkających tam ludzi”'101.

Oznacza to, że wyraz, który w danym języku posiada określoną moc, przełożony na obcy język może stać się bezwartościowy dla obrzędów magicznych. Orygenes wyjaśnia to zjawisko podając przykład wzięty z życia codziennego. Otóż, gdyby dziecku dano określone imię w języku greckim, to gdyby ktoś zawołał je thumacząc jego imię na egipski, łacinę lub jakikolwiek inny język, to dziecko nie zrozumiałoby zawołania i nie wykonałoby polecenia. $Z$ tego też powodu nie wolno zmieniać imienia Boga, ani też odnosić do Niego dowolnych nazw. Stąd w praktykach magów egipskich wezwania imienia Boga Abrahama przynosiło pożądane efekty, zaś przetłumaczone pozostawało niezrozumiałe i nieskuteczne ${ }^{102}$. Dlatego też chrześcijanie wolą ponieść śmierć niż nazywać Boga imionami pogańskich bóstw. Do logiki teorii nazw należy również imię Jezusa, mocą którego chrześcijanie wypędzają złe duchy z opętanych ludzi. Jego własne imię posiada bowiem cudowną moc, która objawia się wśród ludzi ${ }^{103}$.

Z kolei Tertulian naucza, że nazwy nadawane bogom pogańskim to nic nieznaczące i zmyślone nazwy. Niemniej jednak skoro stały się istotną częścią

\footnotetext{
${ }^{98}$ Por. tamże V 45, SCh 147, 128-130, tłum. Kalinkowski, s. 274.

${ }^{99}$ Por. tamże I 24, SCh 132, 138-140, tłum. Kalinkowski, s. 52.

${ }^{100}$ Por. tamże I 25, SCh 132, 140-142, thum. Kalinkowski, s. 53; J. Daniélou, Teologia Judeochrześcijańska, thum. S. Basista, Kraków 2002, 148-160.

${ }^{101}$ Origenes, Contra Celsum I 24, SCh 132, 138: „,

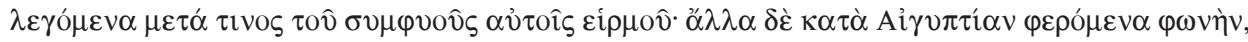

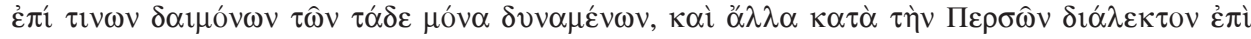

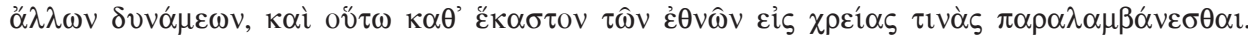

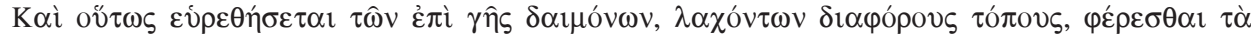

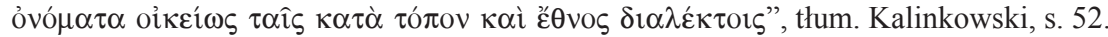

${ }^{102}$ Por. tamże V 45, SCh 147, 130-132, thum. Kalinkowski, s. 274-275.

${ }^{103}$ Por. tamże I 25, SCh 132, 142, tłum. Kalinkowski, s. 53; Hasenfratz, Religie świata starożytnego a chrześcijaństwo, s. 102.
} 
zabobonu, czyli bałwochwalstwa, to niejako przyciągają one wszelkie duchy nieczyste przez zabobonną (superstitio) praktykę ${ }^{104}$.

Te dwie płaszczyzny polemiki z myśleniem pogańskim i magicznym podkreślają moc imienia Bożego i pierwszorzędną rolę Chrystusa w praktyce egzorcyzmu. Niemniej jednak pamiętać należy, że modlitwa za opętanych wymaga spełnienia jeszcze innych warunków, gdyż, jak każde błaganie zanoszone do Boga, potrzebuje ona zaangażowania człowieka. W analizie egzorcyzmu nie może więc zabraknąć również tego wątku.

3. Egzorcyzm jako modlitwa czlowieka wierzącego. Orygenes zauważa, że skoro egzorcyzmy prowadzone w imię Chrystusa czerpią swą skuteczność z mocy samego Boga, to mogą ich dokonywać zwyczajni ludzie. Nie potrzeba więc do nich mędrca, który potrafiłby dowodzić prawd wiary i prowadzić teologiczne rozważania, gdyż żaden naukowy argument nie jest w stanie przekonać złego ducha, by opuścił zniewolonego przez siebie człowieka ${ }^{105}$. Tertulian zaś zaświadcza o egzorcyzmach prowadzonych nawet przez chrześcijan, którzy sami mieli trudności z unikaniem jakiegokolwiek zaangażowania w sprawy kultu pogańskiego ${ }^{106}$.

Ta niedoskonałość i prostota chrześcijan dokonujących egzorcyzmu umożliwia - jak wspomniano wyżej - objawienie się łaski Chrystusa zawartej w nauce Ewangelii, gdyż dla wszystkich staje się oczywiste, że uwolnienie człowieka nie jest dziełem świętości życia ani mądrości tych, którzy wydają rozkazy demonom. Co więcej, słabość egzorcystów eksponuje również nędzę i bezsilność złych duchów, które jako związane mocą imienia Chrystusa, muszą być posłuszne zwyczajnym ludziom. Dlatego też - jak zaznacza Orygenes - do wypędzenia demonów nie potrzeba znać skomplikowanych zaklęć magicznych, lecz wystarczy prosta modlitwa ${ }^{107}$.

Chociaż apologeci świadczą o praktykach egzorcyzmów prowadzonych przez słabych chrześcijan, to jednocześnie podkreślają, że w samym procesie uzdrawiania i uwolnienia z niewoli demonów istotną rolę odrywa również wiara tych, którzy modlą się za opętanych. Orygenes potwierdza bowiem, że już słowa Ewangelii odczytywane w obecności ludzi zniewolonych, często wypędzają złe duchy, zwłaszcza wówczas, gdy są wypowiadane szczerze,

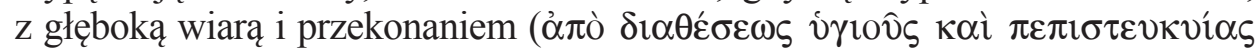

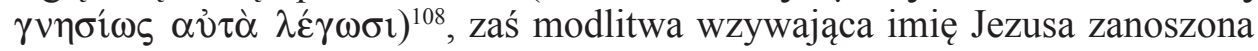

${ }^{104}$ Por. Tertullianus, De idolatria 15, 5-6, CCL 2, 1116, PSP 65, 142.

${ }^{105}$ Por. Origenes, Contra Celsum VII 4, SCh 150, 22, thum. Kalinkowski, s. 342-343.

${ }^{106}$ Por. Tertullianus, De idolatria 11, 7-8, CCL 2, 1111, PSP 65, 137-138; tenże, De corona 11, 1-3, ed. Aem. Kroymann, CCL 2, Turnhout 1954, 1056-1057, tłum. T. Skibiński: Tertulian, O wień$c u$, PSP 65, 118-119.

${ }^{107}$ Por. Origenes, Contra Celsum VII 4, SCh 150, 22, thum. Kalinkowski, s. 342-343.

${ }^{108}$ Por. tamże I 6, SCh 132, 90, thum. Kalinkowski, s. 39. Zob. Zalewski, Walka z osobowym złem, s. 194. 
do Boga przez ludzi prawdziwie wierzących leczy z chorób, wyzwala z opętania i zaradza wielu innym nieszczęściom, jakie człowiek musi znosić na ziemi ${ }^{109}$. Dzieje się tak, ponieważ złe duchy nęka bardzo ludzkie wyznanie wiary, zaś nabierają one sił wówczas, gdy ktoś wyprze się swej wiary ${ }^{110}$. Również Minucjusz Feliks mówi o wypędzeniu demonów mocą żarliwej modlitwy (orationis incendiis de corporibus exiguntur) ${ }^{111}$. Jego zdaniem skuteczność i szybkość procesu wypędzania demonów zależy zarówno od siły wiary człowieka, który cierpi zniewolenie, jak i od łaski posiadanej przez tego, kto się za niego modli ${ }^{112}$.

Oznacza to, demony, będąc posłuszne chrześcijanom ze względu na moc imienia Jezusa, bardziej boją się tych Jego uczniów, którzy pozostają z Nim złączeni przez świętość życia. Wydaje się bowiem, że owa żarliwa modlitwa przychodzi im znacznie łatwiej niż innym chrześcijanom. Poza tym, demony widząc ich wiarę wyznawaną nie tylko ustami, lecz również poprzez swe czyny, a nawet przez przyznanie się do Chrystusa w obliczu prześladowań, boją się ich obecności i - jak wspomniano wyżej - tracą przy nich swą siłę. W ten sposób świadectwo wiary chrześcijan podkopuje władzę złych duchów nad człowiekiem i ułatwia jego uwolnienie ${ }^{113}$.

Jednocześnie należy podkreślić, że zgodnie ze świadectwem autora Oktawiusza, na skuteczność egzorcyzmów ma również wpływ postawa samego opętanego i siła jego wiary. Proces uwolnienia będzie zatem postępował szybciej i modlitwa chrześcijan będzie tym skuteczniejsza, im bardziej będzie ona współgrała z modlitwą cierpiącego zniewolenie i z jego pragnieniem uwolnienia ${ }^{114}$.

To, co dokonuje się podczas egzorcyzmów, czyli skuteczność modlitw o uwolnienie, zanoszonych do Boga przez chrześcijan, objawienie mocy Bożej, a także ujawnienie kłamstwa demonów, które podają się za bogów, przyczynia się do nawrócenia wielu spośród pogan ${ }^{115}$. Fakt egzorcyzmów stanowi więc dla apologetów rodzaj argumentu w polemice z pogańską idolatrią, a jednocześnie - jak się wydaje - jest ostrzeżeniem dla samych chrześcijan,

${ }^{109}$ Por. Origenes, Contra Celsum VIII 58, SCh 150, 306-308, thum. Kalinkowski, s. 416.
${ }^{110}$ Por. tamże VIII 44, SCh 150, 268-270, thum. Kalinkowski, s. 406- 407.
${ }^{111}$ Minucius Felix, Octavius 27, 5, PL 3, 339, PSP 44, 61.
${ }^{112}$ Por. tamże 27, 5-7, PL 3, 339-340, PSP 44, 61.
${ }^{113}$ Por. Origenes, Contra Celsum VIII 44, SCh 150, 270, thum. Kalinkowski, s. 406. Zob. K. Kertelge, Teufel, Dämonen, Exorcismen, w: Teufel-Dämonen - Besessenheit. Zur Wirklichkeit des Böses, ed. W. Kasper - K. Lehman, Mainz 1978, 35.

${ }^{114} \mathrm{Nie}$ ma w apologiach jednoznacznych wskazówek, które mogłyby wyjaśnić, czy wola człowieka opętanego i jego pragnienie uwolnienia jest warunkiem koniecznym do uwolnienia. Można jedynie wysnuć wniosek z powyższych rozważań, że skoro Bóg szanuje wolę człowieka i pozwala na jego zniewolenie, gdy ten $\mathrm{z}$ własnej woli wzywa demony oddając się kultowi pogańskich bóstw lub praktykom magii, to podobnie postępuje również w przypadku egzorcyzmu.

115 Por. Tertullianus, Apologeticum XXIII 18, CCL 1, 133, POK 20, 116; Irenaeus, Adversus haereses II 32, 4, PG 7, 829; Zalewski, Walka z osobowym złem, s. 193; Kertelge, Teufel, Dämonen, Exorcismen, s. 35. 
by będąc narażeni w codziennym życiu na kontakty z posągami bóstw, obrzędami religijnymi ku ich czci, czy też praktykami magicznymi, potrafili zachować czystość wiary i obyczajów. Istnienie egzorcyzmów przypomina bowiem o możliwości opętania przez demony. Czy zatem wobec tego zagrożenia chrześcijanie są zupełnie bezbronni i wydani na samowolę demonów?

4. Ochrona przed złym duchem. Chrześcijanie w swym życiu spotykają się z rozmaitymi atakami demonów, które pałają do nich tym większą nienawiścią, im bardziej chcieliby oni poznać Boga oraz żyć według Jego woli ${ }^{116}$. Usiłują one zatem skłonić uczniów Chrystusa do powrotu do złego życia oraz doprowadzić do tego, by zaparli się swojej wiary. One również stoją za prześladowaniami, jakich doznaje Kościół ze strony władz państwowych i zwykłych mieszkańców Imperium Romanum ${ }^{117}$.

Życie chrześcijanina widziane $\mathrm{z}$ tej perspektywy jawi się - jak już wspomniano - jako ciągła walka rozgrywana na płaszczyźnie duchowej. Jest ona szczególnie widoczna na arenie egzorcyzmów, kiedy to człowiek wyposażony w moc imienia Bożego walczy z demonami. Apologeci wczesnochrześcijańscy podkreślają jednak, że owa walka nie toczy się pomiędzy równorzędnymi podmiotami, a jej wynik został już ustalony. Jezus zwyciężył bowiem złego ducha, zniszczył religię demonów oraz ustanowił prawa, dzięki którym ludzie mogą być szczęśliwi nie będąc zmuszeni do składania im ofiar. Słowo Boże wspiera tych, którzy pokładają w Nim ufność i wyrzekają się idolatrii pod jakąkolwiek postacią. Chociaż więc - jak twierdzi Orygenes - złe duchy podburzały przeciwko chrześcijanom władców, senat, a nawet całe narody, to jednak Chrystus jest silniejszy od nich wszystkich. Świadectwem tej potęgi i zwycięstwa Jezusa jest rozprzestrzenianie się Kościoła, który pomimo licznych prześladowań zapełnia całą ziemię ${ }^{118}$.

Znakiem owego zwycięstwa jest również ochrona przed działaniem złego ducha, jaką odczuwają chrześcijanie ze strony Mistrza, któremu uwierzyli. Orygenes podkreśla jednak, że nie jest to tylko kwestia wiary, lecz doświadczenia. Dlatego też naucza:

„My zaś, opierając się na doświadczeniu, stwierdzamy stanowczo, że ci, którzy zgodnie z nauką chrześcijańską czczą najwyższego Boga przez Jezusa, którzy żyją zgodnie z Ewangelią, którzy bezustannie, wedle potrzeby dniem i nocą odmawiają ustalone modlitwy, nie są podatni na wpływy magii i demonów. Prawdą jest bowiem, że «Anioł Pański rozłoży obóz warowny wokół bojących się Jego i wyrwie ich od wszelkiego zła» (Ps 34, 8)" "119.

${ }^{116}$ Por. Iustinus, Apologia II 7(8), 2-3, SCh 507, 340, BOK 24, 277.

${ }^{117}$ Por. tamże 1, 2, SCh 507, 320, BOK 24, 271; M. Kieling, Kościót wobec idolatrii na podstawie „Dokumentów Synodów” w latach 50-381, VoxP 30 (2010) t. 55, 275-285.

${ }^{118}$ Por. Origenes, Contra Celsum IV 32, SCh 136, 262-264, thum. Kalinkowski, s. 204; tenże, In Numeros hom. 12, 4, PG 12, 665-666, PSP 34/1, 128.

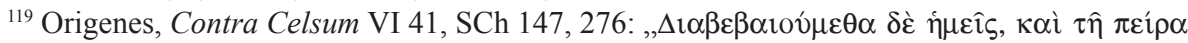


Wobec tego, nawet jeśli demony odnoszą się do chrześcijan z nienawiścią, to nie mogą wyrządzić im żadnej krzywdy tak długo, jak długo trwają oni w nauce Ewangelii oraz w wierności Chrystusowi. Pobożność jest bowiem tym, co zjednuje im opiekę Boga, który - jak twierdzi Aleksandryjczyk - wciąż posyła swoich aniołów, by broniły ludzi przed demonami ${ }^{120}$. Ma to swoje wyjątkowe znaczenie w czasie odprawiania egzorcyzmów. Świadomość Bożej opieki jest niewątpliwie czynnikiem, który przyczynia się do żarliwej modlitwy, podczas której w sposób bezpośrednio widoczny dla każdego objawia się moc Boga i jego zwycięstwo nad złym duchem.

Powyższa próba rekonstrukcji nauki apologetów wczesnochrześcijańskich na temat zjawiska opętań i kościelnej praktyki egzorcyzmu, opartej zarówno na rozważaniach teologicznych, jak i na doświadczeniu, odsłania duchowe podłoże walki z demonami prowadzonej w imieniu Chrystusa przez chrześcijan. Apologeci, podkreślając sam fakt istnienia opętań i konieczność podejmowania wysiłku żarliwej modlitwy za ludzi zniewolonych, wskazują na zasadniczy dla pierwotnego Kościoła problem duszpasterski, którym jest zagrożenie duchowego zniewolenia oraz konieczność zachowania czujności, by nie poddać się pokusie kultu demonów lub myślenia magicznego, ale prowadzić gorliwe życie w łasce Chrystusa, odważnie wyznawać wiarę i unikać wszystkiego, co nosi w sobie choćby pozór idolatrii.

Jednocześnie myśl apologetów zmierza w stronę podkreślania mocy imienia Chrystusa, przed którym drżą wszystkie demony. Chociaż więc opętania stanowią rodzaj walki o panowanie królestwa Bożego, to egzorcyzmy są w głównej mierze objawieniem potęgi Boga i Jego zwycięstwa nad złym duchem, a także zdemaskowaniem kłamstwa demonów, podających się za bogów i żądających dla siebie ofiar oraz boskiej czci. Dzięki temu egzorcyzmy stanowią poważny argument $\mathrm{w}$ polemice $\mathrm{z}$ pogańską kulturą, a także są przyczyną wielu nawróceń ludzi zdumionych realnym i namacalnym działaniem Boga.

Przekaz, jaki proponują apologeci, posiada zatem przede wszystkim wymiar pozytywny. Dostrzegając zagrożenia dla życia duchowego, akcentują oni zwycięstwo Jezusa, a istniejące zło nie zasłania im obecności dobra wynikającego z przynależności do Chrystusa. Dlatego też nawet krytyka bałwochwal-

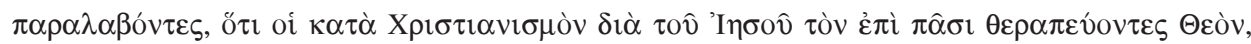

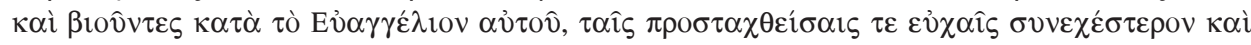

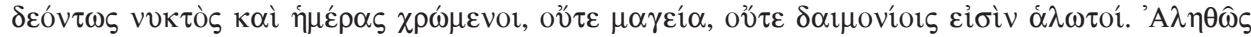

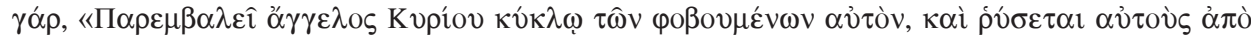

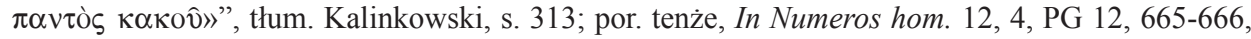
PSP 34/1, 128; tamże, 13, 6, PG 12, 673-674, PSP 34/1, 136.

${ }^{120}$ Por. Origenes, Contra Celsum VIII 27, SCh 150, 232-234, thum. Kalinkowski, s. 397. 
stwa i magii oraz opisywana przez nich praktyka egzorcyzmu są w istocie zaproszeniem skierowanym do wszystkich ludzi, by przyjęli orędzie Ewangelii i uznali w Chrystusie swego Boga i Zbawiciela.

\section{POSSESSION AND EXORCISMS \\ IN THE EARLY CHRISTIAN APOLOGETICS OF $2^{\mathrm{ND}}$ AND $3^{\mathrm{RD}}$ CENTURY}

\section{(Summary)}

The article is the attempt to analyze the teaching of early christian apologists about possession and exorcisms in Church. They recognize that possession in the strict sense applies to a human body. By contrast, spiritual enslavement consists in introducing someone into impiety. Evil spirits, after turning away from their Creator, envy people the grace of God and try to take them away from God and to enslave. They claim to be gods and demand sacrifices and a cult. Magic is also the way to enslavement, because the effectiveness of magic is connected with the power of demons.

An exorcism is a kind of spiritual fight in which a christian, in the name of Jesus, commands demons and liberates the possessed person. Exorcisms are the manifestation of God's power, which beats evil spirits and exposes their lies. Although the main reason of the liberation is the power of God's name, faith and ardent prayer of a possessed person and these who pray for him have also an impact on that process. Christians who live in the grace of God are under the care of Christ, so they don't have to fear demons.

Słowa kluczowe: apologia, bałwochwalstwo, bezbożność, demon, egzorcyzm, Kościół, magia, modlitwa, imię Boże, opętanie.

Key words: apologia, idolatry, impiety, demon, exorcism, Church, magic, prayer, God's name, possession. 
